\title{
Endoplasmic Reticulum Associated Protein Degradation (ERAD) in the Pathology of Diseases Related to TGF $\beta$ Signaling Pathway: Future Therapeutic Perspectives
}

OPEN ACCESS

Edited by:

Daniela Liccardo,

Temple University, United States

Reviewed by:

Mirjana Jerkic,

Keenan Research Centre for

Biomedical Science of St. Michael's

Hospital, Canada

Michal Mielcarek,

Imperial College London,

United Kingdom

${ }^{*}$ Correspondence: Bassam R. Al

bassam.ali@uaeu.ac.ae

Specialty section:

This article was submitted to

Molecular Diagnostics

and Therapeutics,

a section of the journal

Frontiers in Molecular Biosciences

Received: 23 June 2020 Accepted: 29 September 2020

Published: 29 October 2020

Citation:

Gariballa N and Ali BR (2020) Endoplasmic Reticulum Associated

Protein Degradation (ERAD) in the Pathology of Diseases Related to TGF $\beta$ Signaling Pathway: Future

Therapeutic Perspectives.

Front. Mol. Biosci. 7:575608. doi: 10.3389/fmolb.2020.575608

\begin{abstract}
Nesrin Gariballa ${ }^{1,2}$ and Bassam R. Ali, ${ }^{1,2,3 *}$
${ }^{1}$ Department of Pathology, College of Medicine and Health Sciences, United Arab Emirates University, Al Ain, United Arab Emirates, ${ }^{2}$ Department of Genetics and Genomics, College of Medicine and Health Sciences, United Arab Emirates University, Al Ain, United Arab Emirates, ${ }^{3}$ Zayed Bin Sultan Center for Health Sciences, United Arab Emirates University, Al Ain, United Arab Emirates
\end{abstract}

The transforming growth factor signaling pathway (TGF $\beta$ ) controls a wide range of cellular activities in adulthood as well as during embryogenesis including cell growth, differentiation, apoptosis, immunological responses and other cellular functions. Therefore, germline mutations in components of the pathway have given rise to a heterogeneous spectrum of hereditary diseases with variable phenotypes associated with malformations in the cardiovascular, muscular and skeletal systems. Our extensive literature and database searches revealed 47 monogenic diseases associated with germline mutations in 24 out of 41 gene variant encoding for TGF $\beta$ components. Most of the TGF $\beta$ components are membrane or secretory proteins and they are therefore expected to pass through the endoplasmic reticulum (ER), where fidelity of proteins folding is stringently monitored via the ER quality control machineries. Elucidation of the molecular mechanisms of mutant proteins' folding and trafficking showed the implication of ER associated protein degradation (ERAD) in the pathogenesis of some of the diseases. For example, hereditary hemorrhagic telangiectasia types 1 and $2(\mathrm{HHT} 1$ and $\mathrm{HHT} 2$ ) and familial pulmonary arterial hypertension (FPAH) associated with mutations in Endoglin, ALK1 and BMPR2 components of the signaling pathway, respectively, have all exhibited loss of function phenotype as a result of ER retention of some of their disease-causing variants. In some cases, this has led to premature protein degradation through the proteasomal pathway. We anticipate that ERAD will be involved in the mechanisms of other TGF $\beta$ signaling components and therefore warrants further research. In this review, we highlight advances in ER quality control mechanisms and their modulation as a potential therapeutic target in general with particular focus on prospect of their implementation in the treatment of monogenic diseases associated with TGF $\beta$ components including $\mathrm{HHT} 1, \mathrm{HHT}$, and $\mathrm{PAH}$. In particular, we emphasis the need to establish disease mechanisms and to implement such novel approaches in modulating the molecular pathway of mutant TGF $\beta$ components in the quest for restoring protein folding and trafficking as a therapeutic approach.

Keywords: transforming growth factor, hereditary hemorrhagic telangiectasia, pulmonary arterial hypertension, ERAD, endoglin, BMPR2, ALK1 


\section{INTRODUCTION}

Transforming growth factor (TGF $\beta$ ) signaling pathway plays crucial roles in a diverse set of cellular activities such as cell growth, differentiation, immunological responses, apoptosis and during embryogenesis (Bobik, 2006; Caja et al., 2018; Goumans and Ten Dijke, 2018). The human genome encodes 42 of the TGF $\beta$ family protein ligands, which can be divided into two groups according to their sequence similarity and the pathways they activate (Lander et al., 2001). The first group includes the TGF $\beta$, Activin and Nodal protein ligands while the second group includes bone morphogenetic protein (BMP), growth and differentiation factor (GDF), and Muellerian inhibiting substance (MIS) (Shi and Massagué, 2003).The signaling pathway is initiated via binding of the ligand to serine/threonine type II receptor that phosphorylates and activates the type I receptor which causes dimerization of the type II and type I receptors in a heterotetramic complex. The signal is then propagated to the nucleus through phosphorylation of SMAD transcription factors (Figure 1) (Shi and Massagué, 2003; Groppe et al., 2008).

In addition, the human genome encodes five type II receptors (Activin A Receptor Type 2A; ACVR2A, Activin A Receptor Type 2B; ACVR2B, Bone morphogenetic protein receptor; BMPR2, Activin A receptor like type 2; ACVRL2 and Anti-Müllerian hormone receptor;AMHR2) and seven type I receptors (Activin receptor-like kinase 1-7; ALK1-7) (Hata and Chen, 2016). Unlike type II receptors, type I receptors have a distinctive conserved 30 amino acid Glycine-Serine (GS) region (for the GSGS sequence it contains) that is phosphorylated by type II receptors (Huse et al., 1999). Type I and type II receptors are classified according to their sequence similarities. They are both dual specificity kinases due to having cytoplasmic kinase domain that has both serine/threonine kinase activity and tyrosine kinase activity (Gomez-Puerto et al., 2019). TGF $\beta$ ligands (TGF $\beta 1$, TGF $\beta 2$, and TGF $\beta 3$ ) are dimeric polypeptides that bind with high affinity to the TGF $\beta$ type two receptor, which phosphorylates the type I receptor, whereas, BMPs bind with equal affinity to both type I and type II TGF $\beta$ receptors (Massagué and Chen, 2000; Massagué, 2008; Kashima and Hata, 2018). TGF 3 type III receptors (sometimes referred to as co-receptors) include Betaglycans and Endoglin, which both have no kinase activity, however they can bind all three TGF $\beta$ ligands with high affinity and facilitates ligand binding to TGF $\beta$ type II receptors and hence enhance ligand-receptor complex binding and augment its downstream signaling effect (Vander Ark et al., 2018).

SMADs are considered as the signal transducer in the TGF $\beta$ signaling pathway. They propagate the signal from cell membrane to the nucleus in a context dependence manner. Up to date, eight SMAD proteins have been identified in humans that have been classified into three classes, receptor mediated SMADs (R-SMADs), common partner SMADs (Co-SMADs) and inhibitory SMADs (I-SMADs) (de Caestecker, 2004). R-SMADs include SMAD2 and SMAD3 that are activated in response to binding of Activins and TGF $\beta$ proteins to the TGFBR2 and ACVR1B receptors. On the other hand, R-SMADs such as SMAD1, SMAD5 and SMAD8 are phosphorylated by BMPR2 receptor in response to the binding of BMP proteins. Activation of the second class SMADs (SMAD4-Co SMAD) is receptor independent, however their function is crucial for the receptor regulated SMADs. The third class of SMADs (SMAD6 and SMAD7) function as antagonists that inhibit the signaling of R-SMADs and Co-SMADs by competing with the ligands that trigger receptor phosphorylation. SMAD6 generally inhibits BMP activation, while SMAD7 generally work as a feedback regulator for TGF $\beta$ activation (Moustakas and Heldin, 2009; Pérez-Gómez et al., 2010; Hata and Chen, 2016). Beside the canonical SMAD regulated signaling pathway, TGF $\beta$ ligands can also regulate cellular physiological responses through non-SMAD signaling proteins, which have actually preceded the discovery of SMADs (Moustakas and Heldin, 2005). Non-SMAD signaling proteins downstream of the TGF $\beta$ receptors can attenuate and regulate the signaling pathways in various modes of actions. They can directly interact with type I receptors and become phosphorylated without a direct interaction with SMADs. On the other hand, non-SMAD proteins can transiently interact with SMADs in order to facilitate the activation of signaling pathways such as extracellular signal regulated kinase/mitogen-activated protein kinase (ERK/MAPK) pathways, Rho-like GTPase signaling pathways, and phosphatidylinositol-3-kinase (PI3K)/AKT pathways (Zhang, 2009). ERK/MAP kinase pathway is activated via tyrosine phosphorylation of ShcA by activated TGF $\beta$ type I receptor, followed by the formation of ShcA/Grb2/Sos complex and subsequent activation of Ras GTPase, Raf, MEK and ERK1/2 kinases. ERK1/2 can phosphorylate transcription factors as well as SMADs and hence regulate gene expression (Tzavlaki and Moustakas, 2020). The activation of the MAPK pathway is predominantly observed in epithelial cells triggered by a variety of cell growth stimuli such as insulin, thrombin, epidermal and hematopoietic growth factors (Hartsough and Mulder, 1995). c-Jun N-terminal kinase (JNK) and p38 MAP kinase pathways can also be activated independent of SMAD through the activation of MAP kinase kinases (MKKs). Both JNK and p38 MAP kinase pathways play key roles in a variety of cellular functions such as differentiation, apoptosis and inflammation (Yu et al., 2002). MAP3K7, also known as TGF$\beta$-activated kinase 1 (TAK1), is a well-known activator of p38 MAP kinase pathway downstream of TGF $\beta$ ligands that can also phosphorylate R-SMADs at the linker region promoting a negative feedback regulation of the canonical TGF $\beta$ signaling pathway (Tzavlaki and Moustakas, 2020).

PIK3s exhibit constitutive interaction with type II receptors through its $\mathrm{p} 85$ regulatory unit, while interaction with the type I receptors occurs upon the TGF $\beta$ binding to the receptor complex, which leads to the activation of the PIK3/AKT signaling pathway (Yi et al., 2005). This pathway promotes cellular survival and growth in response to extracellular signals in multiple cellular processes including glucose metabolism, apoptosis and cell proliferation. Activation of PIK3 pathway can also activate mammalian target of rapamycin complex 2 (mTORC2), leading to the phosphorylation of AKT, which collectively contribute to epithelial-mesenchymal transition (EMT) and cell migration (Lamouille et al., 2012).

TGF $\beta$ ligands can also induce the Rho GTPases signaling pathway independent of SMADs regulation. Activation of 


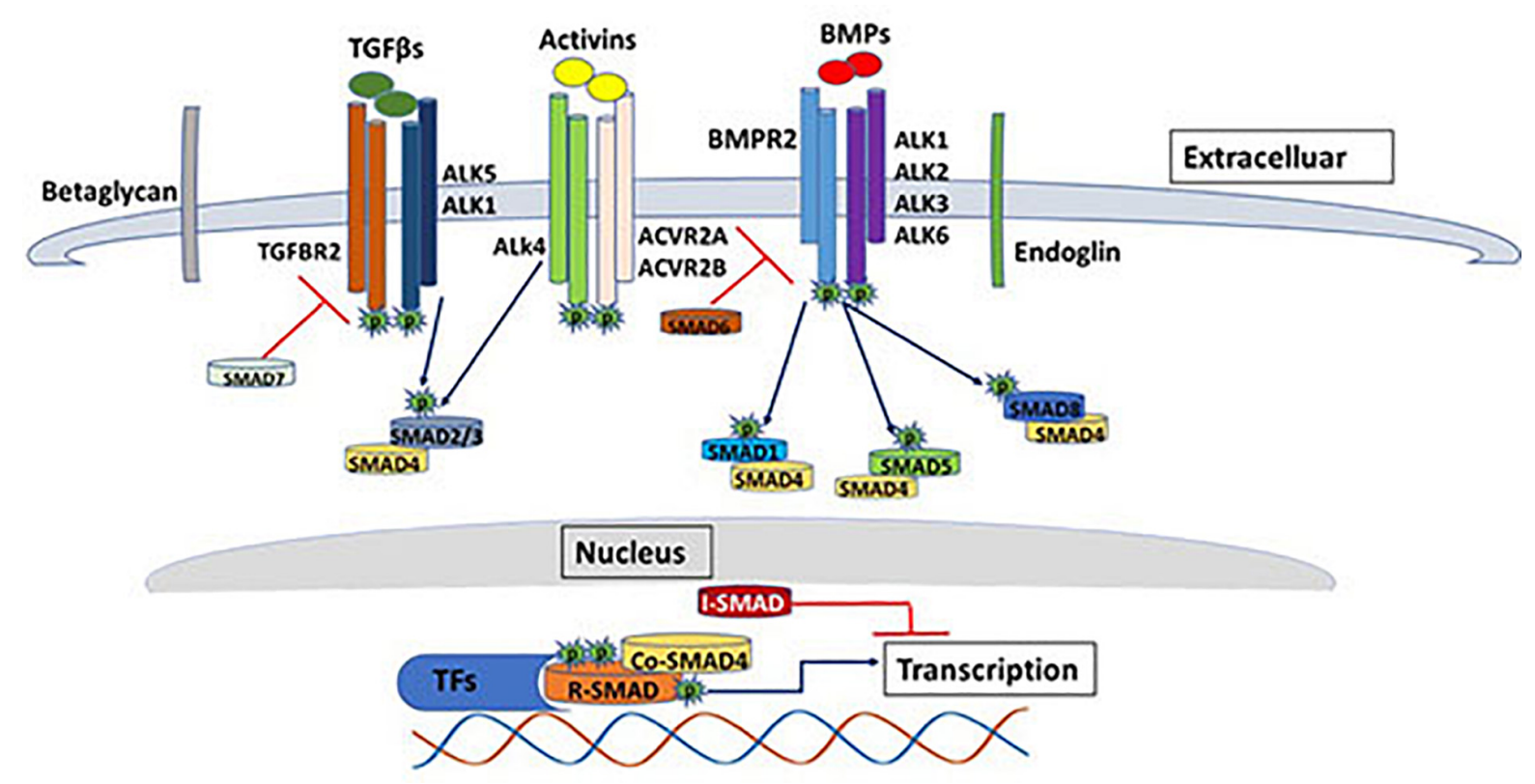

FIGURE 1 | The TGF beta SMAD-dependent signaling pathway. The diagram shows some of the major components of the TGF $\beta$ signaling pathway. SMAD-dependents signal transduction is initiated with the binding of the ligands (e.g., TGF $\beta$, BMP, activins etc.) to the serine/threonine type II receptor that phosphorylates and activates the type I receptor which causes dimerization of the type II and type I receptors in a heterotetrameric complex. The signal is then propagated to the nucleus through phosphorylation of SMAD transcription factors. The image represents only few of the ligands/receptors/SMADs possible signal transduction combinations.

RhoA and Cdc42 GTPases in epithelial cells play key roles in cytoskeleton regulation and cell motility (Edlund et al., 2002). This pathway can also be negatively regulated by Par6, a negative regulator of epithelial cells polarity that is closely associated with TGF $\beta$ type I receptor. Par6 phosphorylation facilitates the recruitment of ubiquitin ligases that labels RhoA GTPase for degradation (Ozdamar et al., 2005).

In addition to the SMAD and non-SMAD regulators of TGF $\beta$ signaling pathways, it is very important to note that cross-talk between the TGF $\beta$ signaling pathway and other pathways can also occur (Luo, 2017). The activation as well as the function of the various components of the TGF $\beta$ pathways are constantly regulated by various signaling pathways that control cellular processes, adding to the complexity and diversity of its functions.

\section{INVOLVEMENT OF TGF $\beta$ SIGNALING PATHWAY COMPONENTS IN SINGLE GENE DISORDERS}

As illustrated in the previous section, TGF $\beta$ signaling pathway plays a key role during the early embryonic developmental stages, in which axis formation and tissue specifications are determined (Harradine and Akhurst, 2006). Therefore, germline mutations in the TGF $\beta$ pathway components have given rise to a heterogeneous spectrum of hereditary diseases with phenotypes mainly associated with malformations in the cardiovascular, muscular and skeletal system. We have conducted an extensive literature and databases searches to document the involvement of mutations in the TGF $\beta$ pathway components in the development of monogenic hereditary diseases. This exercise revealed 47 monogenic diseases associated with genetic mutations in 24 out of 41 TGF $\beta$ components (Table 1 ). The majority of the diseases are autosomal dominant with variable penetrance and expressivity. Similar phenotypes can also arise from mutations affecting connected genes in the signaling pathway such as hereditary hemorrhagic telangiectasia type 1 and 2 (HHT1, HHT2), which are caused by mutations in ENG and ACVRL1, respectively. Our work and that of others have shown that the endoplasmic reticulum quality control (ERQC) pathways play a role in the pathogenesis of some of these diseases, which is the main focus of this manuscript.

\section{ERAD COMPONENTS AND MECHANISMS}

The Endoplasmic Reticulum (ER) has adopted a highly sophisticated, stringent and conserved quality control mechanism known as ER-associated protein degradation (ERAD) to dispose of improperly folded secretory and membrane proteins and orphaned subunits of protein complexes (Preston and Brodsky, 2017; Sun and Brodsky, 2019). ERAD is a complex process that involves the coordination of the functions of many proteins in both the ER and the cytoplasm with input from the nucleus through the unfolded protein response (UPR); a cellular adaptive mechanism to resolve ER stress (Christianson and Ye, 2014). In order for a misfolded protein to be discarded, 
TABLE 1 | Monogenic diseases associated with TGF $\beta$ pathway components.

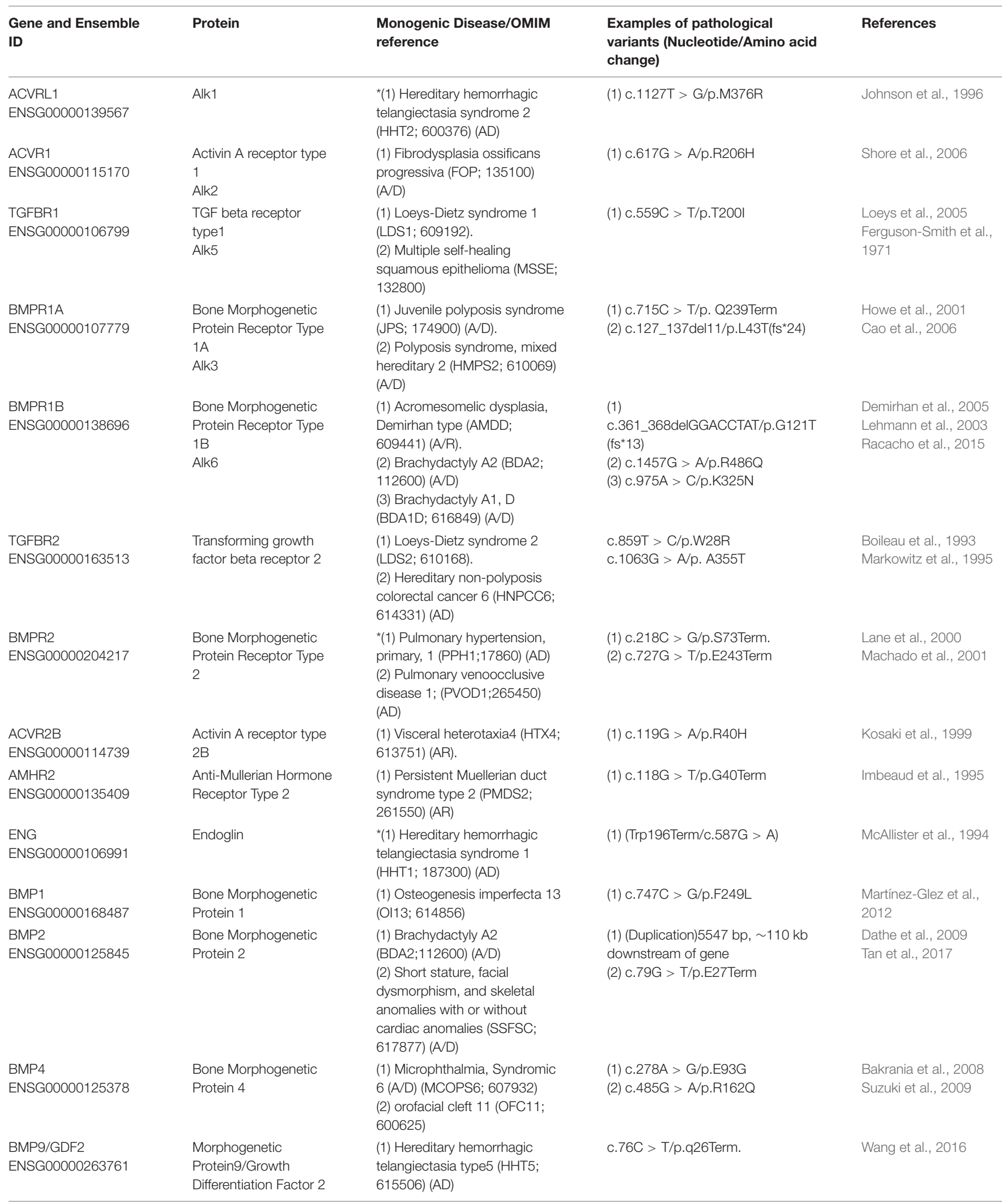


TABLE 1 | Continued

\begin{tabular}{|c|c|c|c|c|}
\hline $\begin{array}{l}\text { Gene and Ensemble } \\
\text { ID }\end{array}$ & Protein & $\begin{array}{l}\text { Monogenic Disease/OMIM } \\
\text { reference }\end{array}$ & $\begin{array}{l}\text { Examples of pathological } \\
\text { variants (Nucleotide/Amino } \\
\text { acid change) }\end{array}$ & References \\
\hline $\begin{array}{l}\text { GDF1 } \\
\text { ENSG00000130283 }\end{array}$ & $\begin{array}{l}\text { Growth Differentiation } \\
\text { Factor } 1\end{array}$ & $\begin{array}{l}\text { (1) Congenital heart defects, multiple } \\
\text { types, } 6 \text { (CHTD6; 613854) (AD). } \\
\text { (2) Right atrial isomerism (RAl; } \\
\text { 208530) }\end{array}$ & $\begin{array}{l}\text { (1) } c .203 G>A / p . R 68 H \\
\text { (2) c. } 1322 T>C / L 441 P\end{array}$ & $\begin{array}{l}\text { Karkera et al., } 2007 \\
\text { Eronen et al., } 2004\end{array}$ \\
\hline $\begin{array}{l}\text { GDF3 } \\
\text { ENSG00000184344 }\end{array}$ & $\begin{array}{l}\text { Growth Differentiation } \\
\text { Factor } 3\end{array}$ & $\begin{array}{l}\text { (1) Klippel-feil syndrome } 3 \text { (KFS3; } \\
613702)(A D) . \\
\text { (2) Microphthalmia, isolated, } 7 \\
\text { (MCOP7; 613704) (AD). } \\
\text { (3) Microphthalmia, isolated, with } \\
\text { Coloboma } 6 \text { (MCOPCB6; 613703) } \\
\text { (AD). }\end{array}$ & $\begin{array}{l}\text { (1) } c .796 C>T / p . R 266 C \\
\text { (2) } c .914 T>C / p . R 195 Q \\
\text { (3) } c 820 C>T / p R 274 W\end{array}$ & Ye et al., 2010 \\
\hline $\begin{array}{l}\text { GDF5 } \\
\text { ENSG00000125965 }\end{array}$ & $\begin{array}{l}\text { Growth Differentiation } \\
\text { Factor } 5\end{array}$ & $\begin{array}{l}\text { (1) Acromesomelic chondrodysplasia } \\
\text { Hunter-Thomson type } \\
\text { (AMDH;201250) (AR). } \\
\text { (2) Acromesomelic chondrodysplasia, } \\
\text { Grebe type (AMDG; 200700) (AR) } \\
\text { (3) Brachydactyly C (BDC;113100) } \\
\text { (AD and AR) } \\
\text { (4) Du Pan syndrome (DUPANS; } \\
\text { 228900) (AR) } \\
\text { (5) Symphalangism, proximal 1B } \\
\text { (SYM1B; 615298) } \\
\text { (6) Multiple synostoses syndrome } 2 \\
\text { (SYNS2; 610017). } \\
\text { (7) Brachydactyly A2 (BDA2; 112600). } \\
\text { (8) Osteoarthritis } 5 \text { (OS5; 612400) } \\
\text { (9) Brachydactyly A1, C (BDA1C; } \\
\text { 615072) }\end{array}$ & $\begin{array}{l}\text { (1/2) c. } 1199 \mathrm{G}>\mathrm{A} / \mathrm{p} . \mathrm{C} 400 \mathrm{Y} \\
\text { (3) } \\
\text { c. } 122 \text { delG/p.(Gly41Aspfs*46) } \\
\text { (4) c. } 1322 \mathrm{~T}>\mathrm{C} / \mathrm{p} . \mathrm{L} 441 \mathrm{P} \\
\text { (5) c. } 1313 \mathrm{G}>\mathrm{T} / \mathrm{p} . \mathrm{R} 438 \mathrm{~L} \\
\text { (7) c. } 1139 \mathrm{G}>\mathrm{A} / \mathrm{p} . \text { R380Q } \\
\text { (8) c. }-275 \mathrm{C}>\mathrm{T} \text { (Regulatory) } \\
\text { (9) c. } 1195 \mathrm{C}>\mathrm{T} / \mathrm{p} . \text { R399C }\end{array}$ & $\begin{array}{l}\text { Thomas et al., } 1997 \\
\text { Polinkovsky et al., } 1997 \\
\text { Faiyaz-Ul-Haque et al., } \\
2002 \\
\text { Seemann et al., } 2005 \\
\text { Plöger et al., } 2008 \\
\text { Miyamoto et al., } 2007 \\
\text { Byrnes et al., } 2010\end{array}$ \\
\hline $\begin{array}{l}\text { TGFb1 } \\
\text { ENSG00000105329 }\end{array}$ & $\begin{array}{l}\text { Transforming Growth } \\
\text { Factor Beta } 1\end{array}$ & $\begin{array}{l}\text { (1) Camurati-Engelmann disease } \\
\text { (CAEND; 131300) } \\
\text { (2) Inflammatory bowel disease, } \\
\text { immunodeficiency and } \\
\text { encephalopathy (IBDIMDE; 618213) }\end{array}$ & $\begin{array}{l}\text { (1) } c .652 \mathrm{C}>\mathrm{T} / \mathrm{p} \cdot \mathrm{R} 218 \mathrm{C} \\
\text { (2) } c .328 \mathrm{C}>\mathrm{T} / \mathrm{p} \cdot \mathrm{R} 110 \mathrm{C}\end{array}$ & $\begin{array}{l}\text { Kinoshita et al., } 2000 \\
\text { Kotlarz et al., } 2018\end{array}$ \\
\hline $\begin{array}{l}\text { TGFb2 } \\
\text { ENSG00000092969 }\end{array}$ & $\begin{array}{l}\text { Transforming Growth } \\
\text { Factor Beta2 }\end{array}$ & $\begin{array}{l}\text { (1) Loeys-Dietz syndrome } 4 \text { LDS4; } \\
614816 \text { (AD) }\end{array}$ & (1) c.297C > A/p.Y99Term. & Lindsay et al., 2012 \\
\hline $\begin{array}{l}\text { TGFb3 } \\
\text { ENSG00000119699 }\end{array}$ & $\begin{array}{l}\text { Transforming Growth } \\
\text { Factor Beta }\end{array}$ & $\begin{array}{l}\text { (1) Loeys-Dietz syndrome } 4 \text { (LDS5; } \\
\text { 615582) (AD) } \\
\text { (2) Arrhythmogenic right ventricular } \\
\text { dysplasia-1 (ARVD1; 107970) }\end{array}$ & $\begin{array}{l}\text { (1) } c .1226 G \text { > A/p.C409Y } \\
\text { (2) c. }-30 G \text { > A (Regulatory) }\end{array}$ & $\begin{array}{l}\text { Rienhoff et al., } 2013 \\
\text { Rampazzo et al., } 2003 \text {; } \\
\text { Beffagna et al., } 2005\end{array}$ \\
\hline $\begin{array}{l}\text { SMAD3 } \\
\text { ENSG00000166949 }\end{array}$ & SMAD Family Member & $\begin{array}{l}\text { (1) Loeys-Dietz syndrome } 3 \text { (LDS3; } \\
613795)(A D)\end{array}$ & (1) c.782C > T/p.T261l & van de Laar et al., 2011 \\
\hline $\begin{array}{l}\text { SMAD4 } \\
\text { ENSG00000141646 }\end{array}$ & SMAD Family Member & $\begin{array}{l}\text { (1) Juvenile polyposis } \\
\text { syndrome/hereditary hemorrhagic } \\
\text { telangiectasia syndrome (JPS; } \\
\text { 174900) (AD) } \\
\text { (2) (JP/HHT) (JPHT, 175050) (AD), } \\
\text { (3) Myhre syndrome (MYHRS; } \\
\text { 139210) }\end{array}$ & $\begin{array}{l}\text { (1) c.1042_1043delGT/ } \\
\text { p.(Val348Tyrfs*3) } \\
\text { (2) c. } 1157 G>\text { A/p.G386D } \\
\text { (3) } c .1500 A>\text { G/p.1500M }\end{array}$ & $\begin{array}{l}\text { Howe et al., } 1998 \\
\text { Burger et al., } 2002 \\
\text { Le Goff et al., } 2011\end{array}$ \\
\hline $\begin{array}{l}\text { SMAD6 } \\
\text { ENSG00000137834 }\end{array}$ & SMAD Family Member & $\begin{array}{l}\text { (1) Aortic valve disease (AOVD2; } \\
614823 \text { ) } \\
\text { (2) Craniosynostosis (CRS7; 617439) } \\
\text { (3) Radioulnar synostosis (RUS; } \\
\text { 179300) }\end{array}$ & $\begin{array}{l}\text { (1) c. } 1244 C>T / p . P 415 L \\
\text { (2) } c .968 C>T / p . P 323 L \\
\text { (3) } c .461 G>\text { A/p.G154D }\end{array}$ & $\begin{array}{l}\text { Tan et al., } 2012 \\
\text { Timberlake et al., } 2016 \\
\text { Yang et al., } 2019\end{array}$ \\
\hline $\begin{array}{l}\text { SMAD8/9 } \\
\text { ENSG00000120693 }\end{array}$ & SMAD Family Member & $\begin{array}{l}\text { (1) Primary pulmonary hypertension } 2 \\
\text { (PPH2; 615342) }\end{array}$ & (1) c.606C > A/p.C202* & Shintani et al., 2009 \\
\hline
\end{tabular}

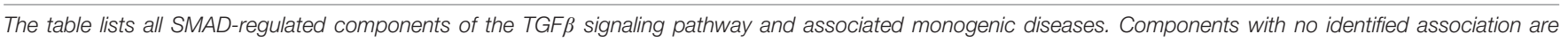

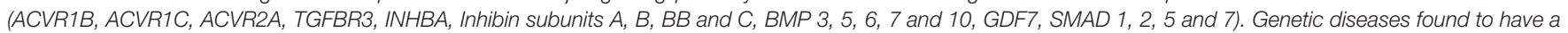
possible ERAD pathology are denoted with an asterisk*. AR, autosomal recessive; $A D$, autosomal dominant. 
it needs to be recognized, retrotranslocated into the cytosol, polyubiquitinated and then extracted from the ER membrane to be degraded in the cytosol by the ubiquitin/proteasomal system (Figure 2) (Wu and Rapoport, 2018).

Newly synthesized proteins that successfully attain native conformations and assemble into complexes, if needed, with the assistance of resident ER molecular chaperones are usually allowed to be incorporated into vesicles and transported further to reach their final destinations and organelles within the secretory pathway or be secreted outside the cell (Needham and Brodsky, 2013). However, fully or partially misfolded proteins and orphaned proteins are retained in the ER and then usually get degraded by the ubiquitin proteasomal systems (Sun and Brodsky, 2019). On the other hand, it became clear recently that some misfolded proteins aggregate in the secretory pathway and are targeted and degraded by autophagy (Qi et al., 2017). Therefore, recently, the umbrella term ERALD (ERto-lysosomes-associated degradation) for autophagic and nonautophagic pathways triggered by ERAD-resistant misfolded proteins, has been proposed (Fregno and Molinari, 2019). Figure 2 shows the possible fates and stages of ER misfolded proteins. Proteins that are structurally mutated are likely to fail reaching the proper conformation and will possibly be transiently trapped in the ER. The length of stay in the ER before the decision to degrade the misfolded or malfolded protein varies from one protein to another. Accumulation of misfolded proteins in the ER is often cytotoxic and may cause ER stress leading to an array of metabolic, immune and degenerative diseases (Sha et al., 2011; Hetz, 2012; Zito, 2019). In addition, unresolved mutated proteins may form aggregates that disrupt ER homeostasis and trigger UPR that activates expression of molecular chaperones that can process aberrant proteins as well as transcription factors that attenuate protein translation to reduce protein synthesis load on the ER (Nishikawa et al., 2005). The first and perhaps the most crucial step in ERAD is the recognition of an ERAD substrate in the highly crowded ER environment that harbors a whole spectrum of newly synthesized proteins in varying stages of their folding, oligomerization and post-translation modifications. Therefore, commitment to degrade a particular protein through ERAD is highly specific and must, therefore, be very tightly controlled. In order to differentiate between permanently misfolded and partially folded

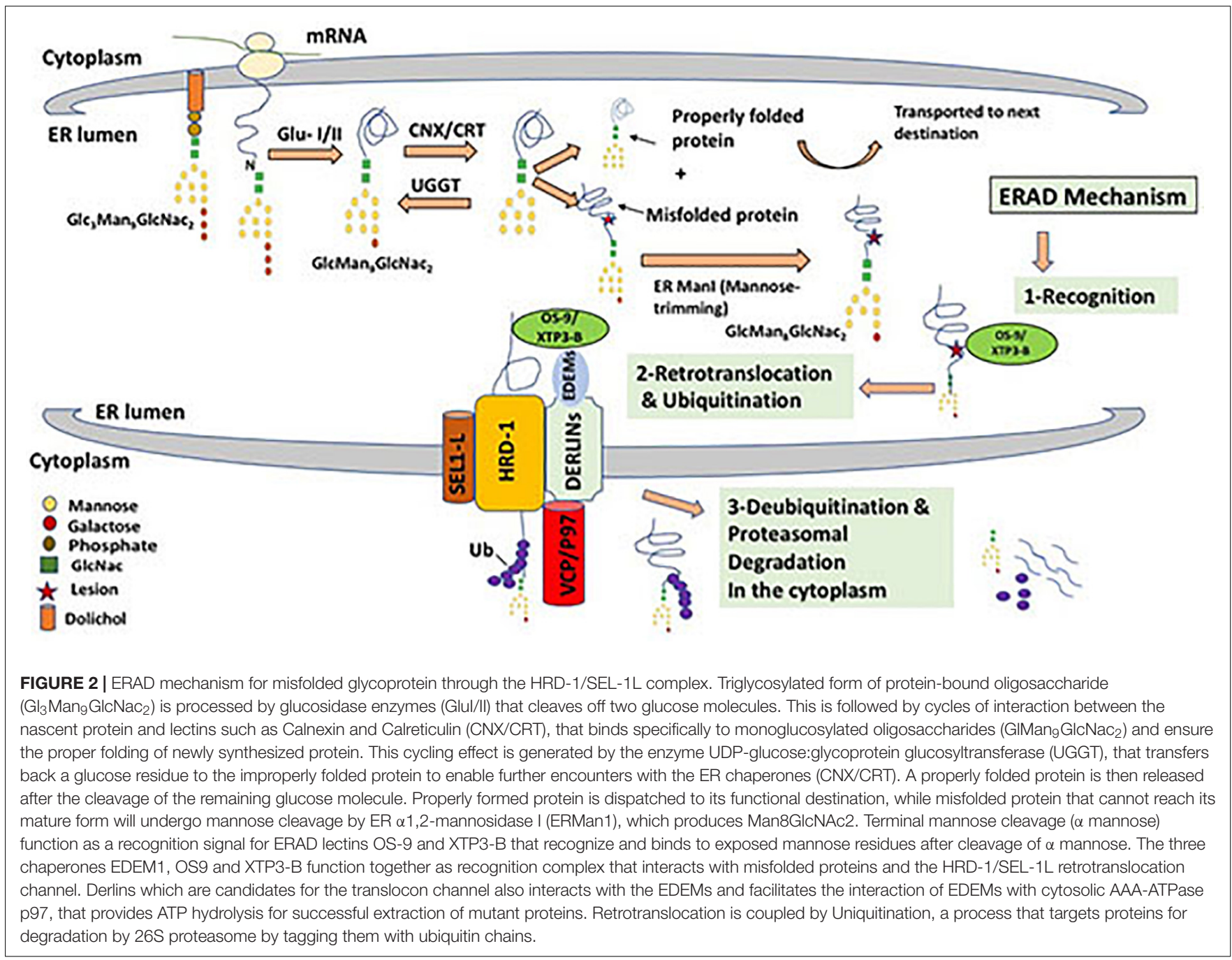


native proteins, both protein species are kept in their soluble form bound to the mammalian ER molecular chaperone Hsp70 (BiP in mammals). $\mathrm{BiP}$ recognizes the exposed hydrophobic regions of improperly folded protein species and plays a key role in folding, or otherwise, disposal through the ERAD pathway due to the prolonged association with BiP (Stevenson et al., 2016). On the other hand, N-linked glycoproteins have a characteristic and well-defined glycan moiety of three glucose, nine mannose, and two $N$-acetylglucosamine residues (Glc3-Man9-GlcNAc2). Glucosidases (GLU I and II) catalyze the cleavage of two glucose residue from a triglycosylated form of protein-bound oligosaccharide and hence facilitate the binding of ER molecular chaperones to monoglycosylated glycoproteins $\left(\mathrm{GlMan}_{9} \mathrm{GlcNac}_{2}\right.$ ) which in turn play a crucial role in glycoprotein folding and processing (Ruggiano et al., 2014; Tax et al., 2019). Glycoprotein lectins such as calnexin and calreticulin (CNX/CRT) facilitate protein folding through repeated cycles of interaction with nascent proteins via their high binding affinity to the mono-glucose residue. However, if the protein fails to fold properly these two chaperones recognize specific $\mathrm{N}$-linked carbohydrate moiety structures that are associated with glycoproteins and target them for ERAD. Terminally misfolded glycoproteins are extracted from CNX/CRT by members of the EDEM (ER degradationenhancing $\alpha$-mannosidase-like protein) family (EDEM1-3) and ER mannosidase I. Mannosidase I removes one mannose residue from the glycoprotein in a process known as "mannose trimming" that facilitates substrate transfer from calnexin to EDEM, a step that signals initiation of the ERAD mechanism (Oda et al., 2003; Nishikawa et al., 2005). OS-9 and XTP3$\mathrm{B}$ are other ER resident lectins that bind luminal misfolded glycol proteins to the Hrd1 E3 ligase through the transmembrane adaptor protein (SEL-1L) (Christianson et al., 2008). Once a mutant protein is recognized and selected as a substrate for disposal by ERAD, it is transferred out of the ER to the cytoplasm for degradation through a process referred to as retrotranslocation or dislocation. Despite the fact that the mechanisms by which a mutant protein is channeled through the ER membrane to the cytosol is still not clear, it has been established that E3 ubiquitin ligases coordinate the execution of this crucial step (Ruggiano et al., 2014). The best-characterized E3 ligases in mammalian cells are Hrd1 and GP78, which are both ER multi spanning membrane proteins with a RING domain responsible for the ligase activity in the cytoplasm (Bernasconi et al., 2010; Joshi et al., 2017). In yeast, it has been characterized that E3 ligase complexes are specific to the location of the lesion (mutation) on the ERAD substrate. For example proteins with cytoplasmic lesions (ERAD-C) are degraded through the Doa10 E3 ligase complex, whereas proteins with structural misfolding in their luminal (ERAD-L) or intramembrane (ERAD-M) are degraded through the Hrd1 E3 ligase complex (Vashist and Ng, 2004). Asi E3 ligase complex has recently been identified and its substrates included soluble and intramembrane proteins (Foresti et al., 2014; Stevenson et al., 2016). In mammalians, correlation between the type of ERAD substrate and choice for degradation pathway has also been identified in few cases, however it is still not clear what dictates a particular pathway for mammalian
ERAD substrates and that is primarily due to the complexity of the retrotranslocation channels and its associate proteins (Lemus and Goder, 2014). Unlike in yeast, several mammalian E3 ligases, beside Hrd1 and GP78, have been implicated in the ERAD substrate dislocation such as RMA1, TEB4, RFP2, TRC8, Kf-1, RNF170 and Nixin/ZNRF4 (Claessen et al., 2012). Other ER trans-membranous proteins such as Derlin-1, Derlin-2 and Derlin-3 (Der1p family) also associate with the E3 ligases and other ERAD factors to form a complex retrotranslocation channel spanning the ER membrane. In mammals, Derlins play a major role in the retrotranslocation of luminal substrates, however their exact function remains speculative (Huang et al., 2013; Christianson and Ye, 2014).

It has been identified that ERAD substrate dislocation is driven by a cascade of ubiquitination enzymatic activities that labels defective proteins that should undergo proteasomal degradation with a chain of four or more ubiquitins attached to lysine 48 to be recognized by the $19 \mathrm{~S}$ cap of $26 \mathrm{~S}$ proteasome (Preston and Brodsky, 2017). Ubiquitin ligase enzyme (E1) activates a ubiquitin-conjugating enzyme (E2), of which there are 40 enzymes. They together work in conjunction with a ubiquitin ligase (E3), of which there are 650 enzymes, to transfer ubiquitin to the selected ERAD substrate (Christianson and Ye, 2014; Caldeira et al., 2014). The attachment of a poly-ubiquitin chain to ERAD substrates triggers the recruitment of AAA + ATPase Cdc48 (p97/VCP in mammals) that provides the energy for the extraction of nearly all EAD substrates (Stolz et al., 2011). However, the fact that $\mathrm{p} 97 / \mathrm{VCP}$ is a cytoplasmic protein means it can only interact with luminal ERAD substrates after they are partially out of the ERAD translocon channel, which raises many questions about the origin of the energy that drives the initiation of the retrotranslocation process (Olzmann et al., 2013). Mammalian E2s such as UBE2J1, UBE2J2, and UBE2G2 have also been implicated in the dislocation process, however their specificities toward a particular E3 ligase have not yet been established (Claessen et al., 2012). Ubiquitination in ERAD is also controlled by the opposing effect of deubiquitinases (DUB) that remove ubiquitin chains conjugated with ERAD substrates. DUBs were found to be in close association with p97/VCP and $26 \mathrm{~S}$ proteasome, which suggests their role in substrate dislocation and proteasomal function. It has been proposed that this association facilitates the threading of unfolded proteins to be degraded in the proteolytic chamber of $26 \mathrm{~S}$ proteasome (Pickart and Cohen, 2004; Ernst et al., 2011).

\section{INVOLVEMENT OF ERAD IN DISEASE MECHANISMS}

The ERAD quality control mechanism has been involved in the pathogenesis of numerous genetic conditions including cystic fibrosis, emphysema and Robinow syndrome and Alzheimer Diseases (AD), Parkinson disease and other neuro degenerative diseases (Reviewed in Kaneko et al., 2017). This is simply because almost a third of all the cellular proteins need to be targeted to the ER in transit to their final destinations and are therefore subjected to this highly stringent quality control system (Sun and 
Brodsky, 2019). On one hand, failure of ERAD mechanism to degrade accumulated mutant proteins induces ER stress which often leads to cellular toxicity and possibly cell death. On the other hand, degradation of a mutant, but functional, protein is also likely to deprive the cells of an important functional protein leading to loss of function phenotypes which have been observed for numerous hereditary diseases. HRD1 E3 ligase has been shown to be involved in the elimination of amyloid precursor protein (APP) and therefore prevents its accumulation (Kaneko, 2016). Reduced levels of HRD1 has been observed in cerebral cortex tissues of patients with $\mathrm{AD}$, which implicates the ERAD in the pathogenesis of this disease (Kaneko et al., 2002). Parkin (PARK2), is another ERAD ubiquitin ligase that is involved in the pathogenesis of familial Parkinson diseases (PD) (Ishikawa and Tsuji, 1996). Mutations in PARK2 leads to accumulation of its substrate in the ER leading to ER stress-induced neuronal cells death (Imai et al., 2001). Mutant proteins have also been shown to interfere with ERAD components impairing their functionality in a number of neurodegenerative diseases such as ALS and Huntington disease (Nishitoh et al., 2002, 2008).

\section{HHT1, HHT2, AND FPAH: ANGIOGENIC MOLECULAR PATHOLOGY AND CURRENT IMPLICATION OF ERAD MECHANISM}

Hereditary hemorrhagic telangiectasia types 1 and 2 (HHT1, HHT2) and familial pulmonary arterial hypertension (FPAH) have been associated with mutations in ENG, ACVRL and $B M P R 2$, respectively. The mutant proteins encoded by the three genes (Endoglin, Alk1 and BMPR2) are transmembrane receptors in the TGF $\beta$ signaling superfamily (McAllister et al., 1994; Johnson et al., 1996; Lane et al., 2000).

\section{Endoglin and ALK1}

Endoglin is a homodimeric transmembrane protein that acts as a TGF $\beta$ co-receptor; encoded by the gene $E N G$ on chromosome 9q33-q34.1. It binds with high affinity to TGF $\beta$ ligand as well as BMP9 and BMP10 in the presence of Alk1 and TGFBR2 which ultimately leads to the activation of SMAD $1 / 5 / 8$ transcription factors that enter the nucleus leading to upregulation of genes that promote endothelial cells angiogenesis (Guerrero-Esteo et al., 2002; Castonguay et al., 2011; OllauriIbáñez et al., 2017). Endoglin is predominantly expressed in vascular endothelium of the heart, liver and brain and it is therefore essential for the normal structure of the vascular system in humans (Castonguay et al., 2011). Mutations in ENG result in the vascular disease hereditary hemorrhagic telangiectasia type1 (HHT; OMIM 187300), also known as Osler-RenduWeber syndrome 1, an autosomal dominant vascular syndrome (McAllister et al., 1994). The disease affects 1 in 5000-8000 people, however evidence of the disease may not be present until the age of 30 (Abdalla and Letarte, 2006). Early manifestation of the disease can present in recurrence of nasal bleeds (epistaxis) that may require blood transfusion. The complexity of the disease arises from its variable phenotypic nature, however it is usually presented in adults with either large arteriovenous malformation (AVM) present in the lungs, liver, gastrointestinal tract, and brain or small cutaneous and mucous membrane telangiectases (Richards-Yutz et al., 2010). Telangiectases can develop on the face, lips, fingers, mouth and gastrointestinal tracts leading to hemorrhage and anemia, on the other hand, AVM accounts for devastating consequences such as stroke, fatal hemorrhage and heart failure (Karabegovic et al., 2004).

Hereditary hemorrhagic telangiectasia type 2 (HHT2; OMIM 600376) is caused by mutations in Activin receptor-like kinase gene (ACVRL1) in chromosome 12q13 (Johnson et al., 1996). The gene encodes a type one receptor in the TGF $\beta$ pathway;ALK1. Upon ligands BMP9 and BMP10 binding, a receptor complex of two type II and two type I transmembrane serine/threonine kinase is formed. Activated ALK1 signals a particular transcriptional response through the SMADs transduction pathway (Mehnert et al., 2010; Alaa El Din et al., 2015). Endoglin was shown to enhance BMP9-induced ALK1 signaling pathway in endothelial cells (Nolan-Stevaux et al., 2012).Mutations in ENG and ACVRL1 genes disrupts recruitment of pericytes, that stabilizes endothelial cells during capillary development, leading to capillary malformation in both HHT1 and HTT2 syndromes (Vorselaars et al., 2018). Both HHT1 and HHT2 have similar phenotype and mutations in both genes account for nearly $85 \%$ of all HHT cases while the remaining cases are associated with mutations in SMAD4 or other unknown genes (Gallione et al., 2004). Mutation in the SMAD4 gene actually cause combination of Juvenile polyposis and HHT and only account for $2 \%$ of all HHT cases (McDonald et al., 2011).

TGF $\beta$ signaling pathway has been implicated in the range of cardiovascular diseases due to the key role of the TGF $\beta$ ligand secreted by endothelial cells in stabilizing mature vascular network, reviewed in Goumans and Ten Dijke (2018). Although vasculogenesis is established during embryogenesis, formation of new blood vessels for growing tissues and during wound healing will continue all through an individual's life. Angiogenesis is regulated by a variety of cytokines and growth factors such as TGF $\beta$ and vascular endothelial growth factor VEGF (Ferrari et al., 2009). TGFß1 is a potent proliferation inhibitor and apoptotic inducer in various cell types (Massagué et al., 2000). This key feature facilitates the angiogenic effect of the ligand as apoptosis is required for pruning of the newly formed vessels. Inhibition of the pathway due to genetic mutations or any other external factors can inhibit the apoptotic effect and result in the formation of abnormal vascular network. During angiogenesis VEGF induces endothelial cells proliferation and migration to the extracellular space where new vessels are formed. This stage is followed by a maturation stage when endothelial cells secrete TGF $\beta$ to recruit mesenchymal cells to be differentiated to pericytes and smooth muscle cells (SMCs) that stabilize the newly formed vessel (Carmeliet and Jain, 2011). In the final stages of vascular developments, VEGF steer vascular remodeling and pruning of non-functional sprouts that fail to model in a way that suites that particular tissue needs (Armulik et al., 2011). The process of vessel formation is tightly controlled by angiogenic as 
well as angiostatic factors that halt the angiogenesis in a context dependent manner. However, in pathological conditions such as HHT, angiogenesis lacks the natural fine tuning, which leads to persistent and excessive formation of abnormal vessels such as AVMs. Several animal and clinical studies have implicated angiogenic VEGF in the pathology of HHT, which lead to the proposal of anti VEGF therapies for the management of HHT (Sadick et al., 2005; Shao et al., 2009; Choi et al., 2014). Systematic treatment of HHT patients with the humanized anti-VEGF antibody (bevacizumab, 5-10 $\mathrm{mg} / \mathrm{kg}$ ) have shown improvement in the frequency of epistaxis, the number of required transfusion and improved liver function in patients with severe phenotype (Ardelean and Letarte, 2015). Despite the promising prospect of this therapy, management of side effects such as gastrointestinal bleeding, proteinuria and hypertension remain to be an obstacle (Pavlidis and Pavlidis, 2013). Moreover, the mechanism of action by which bevacizumab exerts theses effects is poorly understood, and also its effects on AVMs in the brain and lungs has not yet been studied. Thalidomide is another drug with anti-angiogenic and immunomodulatory properties that have been tested on HHT. Administration of thalidomide to a group of HHT patients have reduced the frequency of epistaxis, blood transfusion and GI bleeding, however, the thrombogenic nature of the drug have caused side effects including peripheral neuropathy and deep vein thrombosis (Franchini et al., 2013). On the other hand, second-generation analog of thalidomide (lenalidomide) have shown a better safety profile, in addition to its anti-angiogenic properties via the direct inhibition of VEGF production and endothelial cell migration (Teo, 2005). Recently, thalidomide and lenalidomide were also shown to improve mural cell coverage of brain AVMs in mouse model and hence reduce incidence of brain hemorrhage (Zhu et al., 2018). Since then, a lot of research has been carried out in order to improve the efficacy and safety profile of such innovative therapies. However, in recent years the focus has shifted to the molecular pathway through which TGF $\beta$ secretory proteins are transported. The secretory pathway is a complex network of vesicular compartment through which proteins and cellular components are transported from the ER to the Golgi apparatus to the extracellular space, recycled back to the endosome and lysosome (Mercado et al., 2016). Genetic mutations of secretory proteins can lead to their aggregation in the ER lumen and premature degradation through ERAD, a mechanism that is most likely to be implicated in the pathology of HHT type 1 and 2 (Ali et al., 2011; Hume et al., 2013).

Over 400 mutations in ENG have been reported to cause HHT1, however the underlying mechanisms of the disease have not been thoroughly investigated (Mallet et al., 2015). In 2011, we examined the subcellular trafficking of 28 disease-causing missense mutations in ENG. Subcellular localization of wild type and mutant variants of ENG has been examined using both confocal microscope and analysis of their $N$-glycosylation profiles. The results revealed that 10 out of 28 mutants have localized in the ER rather than the endogenous localization in the plasma membrane (Ali et al., 2011). These findings gave an evidence that, in some patients, defective trafficking of endoglin from the ER is the most likely mechanism underlying HHT1.
Functional assays developed to investigate the pathogenicity of Endoglin and ACVRL1 mutations have suggested variable mechanisms for their loss of function including their retention intracellularly in the ER (Ricard et al., 2010; Mallet et al., 2015). We have also shown in a previous study the implication of ERAD mechanism in the pathogenesis of HHT2 caused by ACVRL1 mutations (Hume et al., 2013). Wild-type ALK1 and a number of HHT2 patient mutant variants were expressed as C-terminally tagged EGFP fusion proteins and their localization was tested in HeLa cells. Wild type ALK1 was found to be predominantly targeted to the plasma membrane, where it executes its function as a type 1 TGF $\beta$ receptor. On the other hand, the majority of overexpressed mutant ALK1 proteins were found to be retained in the ER. It was therefore reasonable to predict that defective trafficking of mutant ALK1 receptors, followed by premature degradation through ERAD mechanism are possible mechanism for HHT2 in some patients (Hume et al., 2013).

\section{BMPR2 (Bone Morphogenetic Protein Receptor Type 2)}

BMPR2 encodes for a type II receptor in the TGF $\beta$ signaling superfamily. Mutations in this gene have been identified in $80 \%$ of families with multiple cases of pulmonary arterial hypertension (PAH) (Lane et al., 2000). The remaining 20\% of families affected by the disease are recognized as sporadic; as they have no detectable mutations in currently known disease-associated genes. In addition, 5\% of $\mathrm{PAH}$ patients are actually patients of HHT1 and HHT2 diseases (Simonneau et al., 2013). PAH is generally characterized by elevated arterial pressure caused by abnormal proliferation of endothelial cells of the arteries, which eventually leads to heart failure and death. The disease has similar manifestations in its Familial (FPAH), Idiopathic (IPAH) or sporadic form. Structural changes in the pulmonary vasculature is the main feature of PAH. BMP4 and BMP6 induce vascular endothelial cell proliferation and migration, while BMP9, which is a specific ligand to both BMPR2 and ALK1, was shown to inhibit excessive proliferation and protects endothelial cells from apoptosis (Morrell et al., 2019). This finding may explain the occurrence of PAH diseases in families affected with HHT2 due to mutated ALK1 protein.

There are four distinct functional domains in the mature BMPR2 protein, consisting of extra cellular ligand binding domain, a transmembrane region, a serine/threonine kinase domain (KD), and a cytoplasmic tail domain. The majority of the diseases causing mutation mutations encoding region of BMPR2 are frameshift, nonsense mutation or deletions that triggers mutant mRNA decay through the mechanism nonsense mediated decay (NMD) (Machado et al., 2009). The rest of BMPR2 mutations identified in PAH patients are missense mutations affecting functional domain in the receptor (Li et al., 2010).

Sub-cellular localization of some missense mutant BMPR2 protein in the ligand binding domain affecting highly conserved cysteine residues resulted in retention of the mutant proteins in the ER, whereas mutation in the kinase domains showed localization to both ER and plasma membrane. On the other hand, cytoplasmic tail mutants localized exclusively in the 
plasma membrane (John et al., 2015). These findings consolidate the implication of the ER quality control mechanism in the pathogenesis of FPAH. A study by Satow et al. (2006) has also shown that BMPR2 receptor is degraded via the proteasomal pathway in a negative feedback mechanism promoted by Dullard; a gene involved in neural development in xenopus. Recently, autophagy has also been shown to contribute to the degradation process of BMPR2 receptor in primary human pulmonary artery endothelial cells (PAECs) (Gomez-Puerto et al., 2019). Discrepancy in the results between the two studies probably suggest more than one degradation pathway for the BMPR2 receptor depending on the nature of the mutation and cell type.

Up until now, conventional therapies for $\mathrm{PAH}$ including prostaglandins, phosphodiesterase-5 inhibitors, endothelin receptor antagonists, and soluble guanylate cyclase stimulators aim to improve functional capacity and reduce hospital admissions. However, these vasodilators have not been successful in reversing the disease pathology or reducing the disease mortality rate (Thenappan et al., 2018). Current therapeutic approach for the treatment of $\mathrm{PAH}$ have recently focused on restoring the BMP signaling pathway by using the immunosuppressive drug (tacrolimus). The drug was shown to ameliorate the symptoms in $\mathrm{PAH}$ patients and prevent the development of PAH in BMPR2 deficient mice (Spiekerkoetter et al., 2015; Sommer et al., 2019). Therefore, we predict that functional restoration of defective protein trafficking through ERQC manipulation will open new windows for such innovative therapeutic approaches.

\section{MANIPULATION OF THE ER QUALITY CONTROL AS A THERAPEUTIC TARGET}

Involvement of the ERAD mechanism in the pathogenesis of these diseases potentially opens a window for novel therapeutic targets which involves the manipulation of the ER quality control mechanism to enhance mutant protein folding and trafficking. The quality control of protein-folding in the ER includes chaperone-mediated assistance that can be utilized as a therapeutic targets to salvage mutant proteins from the degradation pathway (Guerriero and Brodsky, 2012). Inhibition of the ERAD pathway through pharmacological and genetic means in order to prolong the retention of mutant protein in the ER has been proven successful in a number of studies. For example, In the case of cystic fibrosis which is caused by a mutation in the cystic fibrosis transmembrane conductance regulator gene (CFTR), proteases regulators that control the folding conformation, quaternary structure of proteins have been utilized to prevent the degradation of partially folded, but functional proteins at the endoplasmic reticulum (Balch et al., 2008). In addition, it has been demonstrated that interference of the p97/VCP and GP78 ERAD complex that interacts with mutant DeltaF508-CFTR for ubiquitination and retrotranslocation out of the ER, prompted partial rescue for the DeltaF508-CFTR (Vij et al., 2006). Continued adjustment of pharmacological modulators of CFTR biogenesis have recently lead to the development of FDA approved drugs such as (Trikafta) and (Kalydeco), both used for the severely misfolded CFTR variants (Estabrooks and Brodsky, 2020). The drugs can repair CFTR misfolded variant, facilitates its escape from ERAD and promotes functionality at the cell membrane.

Lysosomal storage disorders such as Gaucher and Tay-Sachs diseases caused by mutations that affects the native folding of lysosomal enzymes are also candidates for proteasomal degradation via the ERAD mechanism (Wang et al., 2011). Research studies have shown that a combination of ERAD inhibition and upregulation of folding cellular capacity can result in mutant enzyme rescue. ERAD inhibition was achieved through small molecules named kifunensine (Kif) and Eeyarestatin I (EerI), which inhibit ER mannosidase I and p97 ATPase activities, respectively (Wang et al., 2011). Inhibition of p97/VCP has also been used for the rescue of the mutant $\alpha 1$ (A322D) subunit of the GABA inhibitory receptor associated with autosomal dominant juvenile myoclonic epilepsy. A combination of Eeyarestatin I and suberanilohydroxamic acid, a small molecule that enhances protein folding, restored surface expression of $\alpha 1$ (A322D) subunits in cell lines (Han et al., 2015). Genetic diseases such as Wilson's disease and Progressive Familial Intrahepatic 1 cholestasis are also caused by mutations that affect the folding and the subsequent trafficking of the mutant proteins. Molecular chaperones and pharmacological means have been used to restore protein functionality (Hegde et al., 2017). More recently, we have shown that the pharmacological chaperone $N$-n-butyldeoxygalactonojirimycin enhances $\beta$-galactosidase processing and activity in fibroblasts of a patient with infantile GM1gangliosidosis (Mohamed et al., 2020). We have also proposed the modulation of mutant proteins containing the frizzled cysteine-rich domain (FZ-CRD) as a potential therapeutic target (Milhem and Ali, 2019).

Recently, ER stress has been implicated in the pathogenic mechanism of Granular corneal dystrophy type 2 (GCD2) as ER quality control mechanism delays the secretion of mutant TGF $\beta$-induced protein (TGF $\beta$ Ip) through the ER/Golgi secretory pathway (Choi et al., 2016). The use of 4-PBA as therapeutic agent for GCD2 caused significant reduction in the levels of TGFßIp, BiP, and ER stress kinases in GCD2 corneal fibroblasts. These results strongly suggest that the ER quality control system plays a key role in the pathogenesis of GCD2 and proposed the chemical chaperone 4-PBA as a target therapy for this disease (Choi et al., 2016). Melatonin, which is known to suppress cell death through reduction of the UPR or ER stress, has also been used in vitro to relief ER stress in GCD2 corneal fibroblasts, however the exact mechanism of its action has not yet been clarified (Choi et al., 2017). Results from this study have shown reduced expression of the ERAD system components HRD1 and SEL1L, when GCD2 fibroblasts were treated with Melatonin, which makes it a potential therapeutic target for Granular corneal dystrophy type 2 (Choi et al., 2017). Genetic manipulation of the ER quality control mechanism has also been an approach adopted by many due to the latest advances in genetic editing tools. Recently, CRISPR Cas9 technology has been utilized to knockout SEL1L adaptor protein in HEK293 cell line, in order 
to rescue very low-density lipoprotein receptor (VLDLR) mutant protein responsible for Dysequilibrium syndrome (DES) (Ali et al., 2012). The degradation of pathogenic VLDLR and LDLR through ERAD, which is primarily dependent on SEL1-L, was considerably delayed (Kizhakkedath et al., 2018, 2019).

The above examples emphasize the potential of ERQC mechanism manipulation in the search for functional therapy for diseases with defective protein trafficking pathology. The TGF $\beta$ signaling pathway components are classic examples of secretory proteins that undergo stringent quality control checks in the ER. Therefore, TGF $\beta$-associated genetic diseases represents potential candidates for such innovative therapy. However -up to daterestoration of defective protein trafficking in the TGF $\beta$ signaling pathway have only been investigated in few studies. In a study by Sobolewski et al. (2008), they demonstrated the potential for chemical chaperones such as thapsigargin, glycerol and sodium 4-phenylbutyrate (4-PBA) to rescue cell surface expression of mutant BMPR2 expressed in Hela cells. Restored functionality of the mutant receptor has been shown through observation of enhanced activation of SMAD1/3 signaling pathway downstream of the receptor (Sobolewski et al., 2008). In another study by Frump et al., chemical chaperones Tauroursodeoxycholic acid (TUDCA) and 4-PBA have also proven successful in partially restoring cell surface expression of mutant BMPR2 in HPAH patient-derived lymphocytes and in pulmonary endothelial cells (PECs) from HPAH mouse model (Frump et al., 2013).

Despite the small number of research studies that have been conducted for the purpose of restoring the functionality of disease-causing variants of TGF $\beta$ components, the conceptual application of such therapeutic strategy has great potentials. The examples discussed above including the usage of genetic and pharmacological means in order to prolong protein retention in the ER, lay the foundations for similar therapeutic strategies for TGF $\beta$ associated genetic diseases. Furthermore, this concept can be extended to a whole spectrum of disease-causing aberrant proteins with dysfunctional trafficking through the secretory pathway.

\section{CONCLUSION AND FUTURE PERSPECTIVES}

The applicability of novel approaches to a wide range of monogenic diseases with similar pathogenic mechanisms needs to be investigated and considered as potential target for therapy. Despite progress, the full degradation pathways of mutant TGF $\beta$ component proteins such as ALK1, Endoglin, BMPR2 and other TGF $\beta$ components associated with life-limiting conditions have not yet been fully investigated. Future research should therefore focus on the elucidation of the fine details of these mechanisms in order to provide new avenue for personalized therapies. Until this date, conventional drug therapies for these diseases focus on improving the symptoms of the disease rather than modulating the molecular pathway of these aberrant proteins in the quest for restoring their functionality. Recently, however, the angiogenic molecular pathway of endothelial cells have been targeted for the treatment of HTT via inhibition of vascular endothelial growth factor (VEGF) using bevacizumab (antiVEGF antibody) (Buscarini et al., 2019). Other preclinical studies have also identified new molecular targets that are directly linked to the signaling pathway such as (FKBP12), a protein known to interact with the BMP/TGFBRI receptor and represses its catalytic activity (PI3-kinase) downstream of VEGF and also the proangiogenic growth factor (angiopoietin-2) (Ruiz et al., 2017; Robert et al., 2020).

In this review we have shed a light on the possible implications of the ER quality control mechanisms in the pathogenesis of genetic diseases associated with mutations in components of the TGF $\beta$ signaling pathway. Therefore, therapeutic and genetic manipulation of ERAD network in order to enhance mutant protein folding and trafficking, in combination with upregulation of cellular folding capacity via molecular chaperones could be a potential strategy to rescue the localization and activity of mutant protein variants. This strategy is likely to be beneficial for biologically functional mutant proteins trapped in the ER but unable to reach their site of action due to stringent ER quality control mechanism. Hence, missense mutants of Endoglin, Alk1 and BMPR2 that fit these criteria would be an excellent target for an ERAD rescue. We believe that other TGF $\beta$ membrane and secreted components causing monogenic diseases are likely to be substrates for the ER quality control machineries and therefore further research in this area is needed. In addition, in order to make an efficient use of genetic manipulation of the ER quality control mechanism, the correlation between ERAD substrate class and the choice of the degradation channel should be further investigated in mammalian cells and animal models of disease. The realization that the location of the lesion (mutation) may determine a unique ERAD pathway, makes such a correlation essential for the characterization of the degradation pathway for ERAD substrate proteins. Despite all the progress that have been toward understanding the mechanism of ERAD machinery in mammalian cells, many questions about substrate selection and delivery to the proteasome remain unanswered. In order to utilize the full potential of ERAD as a therapeutic target for a spectrum of life-limiting disease, for which no treatment has yet been provided, these gaps are required to be filled through extensive genetic, cellular and biochemical research.

\section{AUTHOR CONTRIBUTIONS}

NG conducted the literature and data base searches, wrote the manuscript draft, and prepared the images and tables. BA proposed the need for writing this review, refined and edited drafts, supervised manuscript progress, and approved the final version. Both authors contributed to the article and approved the submitted version.

\section{FUNDING}

The ERAD projects in BA lab are funded by ADEK through the Abu Dhabi Award for Research Excellence (AARE) (21M136) and UAEU. NG is supported by a full scholarship from UAEU (31M439). 


\section{REFERENCES}

Abdalla, S. A., and Letarte, M. (2006). Hereditary haemorrhagic telangiectasia: current views on genetics and mechanisms of disease. J. Med. Genet. 43, 97-110. doi: 10.1136/jmg.2005.030833

Alaa El Din, F., Patri, S., Thoreau, V., Rodriguez-Ballesteros, M., Hamade, E., Bailly, S., et al. (2015). Functional and splicing defect analysis of 23 ACVRL1 mutations in a cohort of patients affected by hereditary hemorrhagic telangiectasia. PLoS One 10:e0132111. doi: 10.1371/journal.pone.0132111

Ali, B. R., Ben-Rebeh, I., John, A., Akawi, N. A., Milhem, R. M., Al-Shehhi, N. A., et al. (2011). Endoplasmic reticulum quality control is involved in the mechanism of endoglin-mediated hereditary haemorrhagic telangiectasia. PLoS One 6:e26206. doi: 10.1371/journal.pone.0026206

Ali, B. R., Silhavy, J. L., Gleeson, M. J., Gleeson, J. G., and Al-Gazali, L. (2012). A missense founder mutation in VLDLR is associated with Dysequilibrium Syndrome without quadrupedal locomotion. BMC Med. Genet. 13:80. doi: 10 . 1186/1471-2350-13-80

Ardelean, D. S., and Letarte, M. (2015). Anti-angiogenic therapeutic strategies in hereditary hemorrhagic telangiectasia. Front. Genet. 6:35. doi: 10.3389/fgene. 2015.00035

Armulik, A., Genové, G., and Betsholtz, C. (2011). Pericytes: developmental, physiological, and pathological perspectives, problems, and promises. Dev. Cell 21, 193-215. doi: 10.1016/j.devcel.2011.07.001

Bakrania, P., Efthymiou, M., Klein, J. C., Salt, A., Bunyan, D. J., Wyatt, A., et al. (2008). Mutations in BMP4 cause eye, brain, and digit developmental anomalies: overlap between the BMP4 and hedgehog signaling pathways. Am. J. Hum. Genet. 82, 304-319. doi: 10.1016/j.ajhg.2007.09.023

Balch, W. E., Morimoto, R. I., Dillin, A., and Kelly, J. W. (2008). Adapting proteostasis for disease intervention. Science 319, 916-919. doi: 10.1126/science. 1141448

Beffagna, G., Occhi, G., Nava, A., Vitiello, L., Ditadi, A., Basso, C., et al. (2005). Regulatory mutations in transforming growth factor-beta3 gene cause arrhythmogenic right ventricular cardiomyopathy type 1. Cardiovasc. Res. 65 , 366-373. doi: 10.1016/j.cardiores.2004.10.005

Bernasconi, R., Galli, C., Calanca, V., Nakajima, T., and Molinari, M. (2010). Stringent requirement for HRD1, SEL1L, and OS-9/XTP3-B for disposal of ERAD-LS substrates. J. Cell Biol. 188, 223-235. doi: 10.1083/jcb.200910042

Bobik, A. (2006). Transforming growth factor-betas and vascular disorders. Arterioscler. Thromb. Vasc. Biol. 26, 1712-1720. doi: 10.1161/01.ATV. 0000225287.20034.2c

Boileau, C., Jondeau, G., Babron, M. C., Coulon, M., Alexandre, J. A., Sakai, L., et al. (1993). Autosomal dominant Marfan-like connective-tissue disorder with aortic dilation and skeletal anomalies not linked to the fibrillin genes. Am. J. Hum. Genet. 53, 46-54.

Burger, B., Uhlhaas, S., Mangold, E., Propping, P., Friedl, W., Jenne, D., et al. (2002). Novel de novo mutation of MADH4/SMAD4 in a patient with juvenile polyposis. Am. J. Med. Genet. 110, 289-291. doi: 10.1002/ajmg.10411

Buscarini, E., Botella, L. M., Geisthoff, U., Kjeldsen, A. D., Mager, H. J., Pagella, F., et al. (2019). Safety of thalidomide and bevacizumab in patients with hereditary hemorrhagic telangiectasia. Orphanet. J. Rare Dis. 14:28. doi: 10.1186/s13023018-0982-4

Byrnes, A. M., Racacho, L., Nikkel, S. M., Xiao, F., MacDonald, H., Underhill, T. M., et al. (2010). Mutations in GDF5 presenting as semidominant brachydactyly A1. Hum. Mutat. 31, 1155-1162. doi: 10.1002/humu.21338

Caja, L., Dituri, F., Mancarella, S., Caballero-Diaz, D., Moustakas, A., Giannelli, G., et al. (2018). TGF- $\beta$ and the tissue microenvironment: relevance in fibrosis and cancer. Int. J. Mol. Sci. 19:1294. doi: 10.3390/ijms19051294

Caldeira, M. V., Salazar, I. L., Curcio, M., Canzoniero, L. M., and Duarte, C. B. (2014). Role of the ubiquitin-proteasome system in brain ischemia: friend or foe? Prog. Neurobiol. 112, 50-69. doi: 10.1016/j.pneurobio.2013. 10.003

Cao, X., Eu, K. W., Kumarasinghe, M. P., Li, H. H., Loi, C., and Cheah, P. Y. (2006). Mapping of hereditary mixed polyposis syndrome (HMPS) to chromosome 10q23 by genomewide high-density single nucleotide polymorphism (SNP) scan and identification of BMPR1A loss of function. J. Med. Genet 43, e13. doi: 10.1136/jmg.2005.034827

Carmeliet, P., and Jain, R. K. (2011). Molecular mechanisms and clinical applications of angiogenesis. Nature 473, 298-307. doi: 10.1038/nature10144
Castonguay, R., Werner, E. D., Matthews, R. G., Presman, E., Mulivor, A. W., Solban, N., et al. (2011). Soluble endoglin specifically binds bone morphogenetic proteins 9 and 10 via its orphan domain, inhibits blood vessel formation, and suppresses tumor growth. J. Biol. Chem. 286, 30034-30046. doi: 10.1074/jbc. M111.260133

Choi, E. J., Chen, W., Jun, K., Arthur, H. M., Young, W. L., and Su, H. (2014). Novel brain arteriovenous malformation mouse models for type 1 hereditary hemorrhagic telangiectasia. PLoS One 9:e88511. doi: 10.1371/journal.pone. 0088511

Choi, S. I., Lee, E., Akuzum, B., Jeong, J. B., Maeng, Y. S., Kim, T. I., et al. (2017). Melatonin reduces endoplasmic reticulum stress and corneal dystrophyassociated TGFBIp through activation of endoplasmic reticulum-associated protein degradation. J. Pineal. Res. 63:12426. doi: 10.1111/jpi.12426

Choi, S. I., Lee, E., Jeong, J. B., Akuzum, B., Maeng, Y. S., Kim, T. I., et al. (2016). 4-Phenylbutyric acid reduces mutant-TGFBIp levels and ER stress through activation of ERAD pathway in corneal fibroblasts of granular corneal dystrophy type 2. Biochem. Biophys. Res. Commun. 477, 841-846. doi: 10.1016/ j.bbrc.2016.06.146

Christianson, J. C., Shaler, T. A., Tyler, R. E., and Kopito, R. R. (2008). OS-9 and GRP94 deliver mutant alpha1-antitrypsin to the Hrd1-SEL1L ubiquitin ligase complex for ERAD. Nat. Cell Biol. 10, 272-282. doi: 10.1038/ncb1689

Christianson, J. C., and Ye, Y. (2014). Cleaning up in the endoplasmic reticulum: ubiquitin in charge. Nat. Struct. Mol. Biol. 21, 325-335. doi: 10.1038/nsmb.2793

Claessen, J. H., Kundrat, L., and Ploegh, H. L. (2012). Protein quality control in the ER: balancing the ubiquitin checkbook. Trends Cell Biol. 22, 22-32. doi: 10.1016/j.tcb.2011.09.010

Dathe, K., Kjaer, K. W., Brehm, A., Meinecke, P., Nürnberg, P., Neto, J. C., et al. (2009). Duplications involving a conserved regulatory element downstream of BMP2 are associated with brachydactyly type A2. Am J Hum Genet 84, 483-492. doi: 10.1016/j.ajhg.2009.03.001

de Caestecker, M. (2004). The transforming growth factor-beta superfamily of receptors. Cytok. Growth Fact Rev. 15, 1-11. doi: 10.1016/j.cytogfr.2003.10.004

Demirhan, O., Türkmen, S., Schwabe, G. C., Soyupak, S., Akgül, E., Tastemir, D., et al. (2005). A homozygous BMPR1B mutation causes a new subtype of acromesomelic chondrodysplasia with genital anomalies. J. Med. Genet. 42, 314-317. doi: 10.1136/jmg.2004.023564

Edlund, S., Landström, M., Heldin, C. H., and Aspenström, P. (2002). Transforming growth factor-beta-induced mobilization of actin cytoskeleton requires signaling by small GTPases Cdc42 and RhoA. Mol. Biol. Cell 13, 902-914. doi: 10.1091/mbc.01-08-0398

Ernst, R., Claessen, J. H., Mueller, B., Sanyal, S., Spooner, E., van der Veen, A. G., et al. (2011). Enzymatic blockade of the ubiquitin-proteasome pathway. PLoS Biol. 8:e1000605. doi: 10.1371/journal.pbio.1000605

Eronen, M., Kajantie, E., Boldt, T., Pitkänen, O., and Aittomäki, K. (2004). Right atrial isomerism in four siblings. Pediatr. Cardiol. 25, 141-144. doi: 10.1007/ s00246-003-0540-1

Estabrooks, S., and Brodsky, J. L. (2020). Regulation of CFTR Biogenesis by the Proteostatic Network and Pharmacological Modulators. Int. J. Mol. Sci. 21:452. doi: 10.3390/ijms21020452

Faiyaz-Ul-Haque, M., Ahmad, W., Zaidi, S. H., Haque, S., Teebi, A. S., Ahmad, M., et al. (2002). Mutation in the cartilage-derived morphogenetic protein1 (CDMP1) gene in a kindred affected with fibular hypoplasia and complex brachydactyly (DuPan syndrome). Clin. Genet. 61, 454-458. doi: 10.1034/j. 1399-0004.2002.610610.x

Ferguson-Smith, M. A., Wallace, D. C., James, Z. H., and Renwick, J. H. (1971). Multiple self-healing squamous epithelioma. Birth Defects Orig. Artic. Ser. 7, 157-163.

Ferrari, G., Cook, B. D., Terushkin, V., Pintucci, G., and Mignatti, P. (2009). Transforming growth factor-beta 1 (TGF-betal) induces angiogenesis through vascular endothelial growth factor (VEGF)-mediated apoptosis. J. Cell Physiol. 219, 449-458. doi: 10.1002/jcp.21706

Foresti, O., Rodriguez-Vaello, V., Funaya, C., and Carvalho, P. (2014). Quality control of inner nuclear membrane proteins by the Asi complex. Science 346, 751-755. doi: 10.1126/science. 1255638

Franchini, M., Frattini, F., Crestani, S., and Bonfanti, C. (2013). Novel treatments for epistaxis in hereditary hemorrhagic telangiectasia: a systematic review of the clinical experience with thalidomide. J. Thromb. Thrombol. 36, 355-357. doi: $10.1007 / \mathrm{s} 11239-012-0840-5$ 
Fregno, I., and Molinari, M. (2019). Proteasomal and lysosomal clearance of faulty secretory proteins: ER-associated degradation (ERAD) and ER-to-lysosomeassociated degradation (ERLAD) pathways. Crit. Rev. Biochem. Mol. Biol. 54, 153-163. doi: 10.1080/10409238.2019.1610351

Frump, A. L., Lowery, J. W., Hamid, R., Austin, E. D., and de Caestecker, M. (2013). Abnormal trafficking of endogenously expressed BMPR2 mutant allelic products in patients with heritable pulmonary arterial hypertension. PLoS One 8:e80319. doi: 10.1371/journal.pone.0080319

Gallione, C. J., Repetto, G. M., Legius, E., Rustgi, A. K., Schelley, S. L., Tejpar, S., et al. (2004). A combined syndrome of juvenile polyposis and hereditary haemorrhagic telangiectasia associated with mutations in MADH4 (SMAD4). Lancet 363, 852-859. doi: 10.1016/S0140-6736(04)15732-2

Gomez-Puerto, M. C., van Zuijen, I., Huang, C. J., Szulcek, R., Pan, X., van Dinther, M. A., et al. (2019). Autophagy contributes to BMP type 2 receptor degradation and development of pulmonary arterial hypertension. J. Pathol. 249, 356-367. doi: $10.1002 /$ path. 5322

Goumans, M. J., and Ten Dijke, P. (2018). TGF- $\beta$ signaling in control of cardiovascular function. Cold Spring Harb. Perspect. Biol. 10:a022210. doi: 10. 1101/cshperspect.a022210

Groppe, J., Hinck, C. S., Samavarchi-Tehrani, P., Zubieta, C., Schuermann, J. P., Taylor, A. B., et al. (2008). Cooperative assembly of TGF-beta superfamily signaling complexes is mediated by two disparate mechanisms and distinct modes of receptor binding. Mol. Cell 29, 157-168. doi: 10.1016/j.molcel.2007. 11.039

Guerrero-Esteo, M., Sanchez-Elsner, T., Letamendia, A., and Bernabeu, C. (2002). Extracellular and cytoplasmic domains of endoglin interact with the transforming growth factor-beta receptors I and II. J. Biol. Chem. 277, $29197-$ 29209. doi: 10.1074/jbc.M111991200

Guerriero, C. J., and Brodsky, J. L. (2012). The delicate balance between secreted protein folding and endoplasmic reticulum-associated degradation in human physiology. Physiol. Rev. 92, 537-576. doi: 10.1152/physrev.00027.2011

Han, D. Y., Di, X. J., Fu, Y. L., and Mu, T. W. (2015). Combining valosin-containing protein (VCP) inhibition and suberanilohydroxamic acid (SAHA) treatment additively enhances the folding, trafficking, and function of epilepsy-associated $\gamma$-aminobutyric acid, type A (GABAA) receptors. J. Biol. Chem. 290, 325-337. doi: 10.1074/jbc.M114.580324

Harradine, K. A., and Akhurst, R. J. (2006). Mutations of TGFbeta signaling molecules in human disease. Ann. Med. 38, 403-414. doi: 10.1080/07853890 600919911

Hartsough, M. T., and Mulder, K. M. (1995). Transforming growth factor beta activation of $\mathrm{p} 44 \mathrm{mapk}$ in proliferating cultures of epithelial cells. J. Biol. Chem. 270, 7117-7124. doi: 10.1074/jbc.270.13.7117

Hata, A., and Chen, Y. G. (2016). TGF- $\beta$ Signaling from Receptors to Smads. Cold Spring Harb. Perspect. Biol. 8:a022061. doi: 10.1101/cshperspect.a022061

Hegde, R. N., Subramanian, A., Pothukuchi, P., Parashuraman, S., and Luini, A. (2017). Rare ER protein misfolding-mistrafficking disorders: therapeutic developments. Tissue Cell 49(2 Pt. A), 175-185. doi: 10.1016/j.tice.2017.02.001

Hetz, C. (2012). The unfolded protein response: controlling cell fate decisions under ER stress and beyond. Nat. Rev. Mol. Cell Biol. 13, 89-102. doi: 10.1038/ nrm3270

Howe, J. R., Bair, J. L., Sayed, M. G., Anderson, M. E., Mitros, F. A., Petersen, G. M., et al. (2001). Germline mutations of the gene encoding bone morphogenetic protein receptor 1A in juvenile polyposis. Nat. Genet. 28, 184-187. doi: 10.1038/ 88919

Howe, J. R., Roth, S., Ringold, J. C., Summers, R. W., Järvinen, H. J., Sistonen, P., et al. (1998). Mutations in the SMAD4/DPC4 gene in juvenile polyposis. Science 280, 1086-1088. doi: 10.1126/science.280.5366.1086

Huang, C. H., Hsiao, H. T., Chu, Y. R., Ye, Y., and Chen, X. (2013). Derlin2 protein facilitates HRD1-mediated retro-translocation of sonic hedgehog at the endoplasmic reticulum. J. Biol. Chem. 288, 25330-25339. doi: 10.1074/jbc. M113.455212

Hume, A. N., John, A., Akawi, N. A., Al-Awadhi, A. M., Al-Suwaidi, S. S., Al-Gazali, L., et al. (2013). Retention in the endoplasmic reticulum is the underlying mechanism of some hereditary haemorrhagic telangiectasia type 2 ALK1 missense mutations. Mol. Cell Biochem. 373, 247-257. doi: 10.1007/ s11010-012-1496-3
Huse, M., Chen, Y. G., Massagué, J., and Kuriyan, J. (1999). Crystal structure of the cytoplasmic domain of the type I TGF beta receptor in complex with FKBP12. Cell 96, 425-436. doi: 10.1016/s0092-8674(00)80555-3

Imai, Y., Soda, M., Inoue, H., Hattori, N., Mizuno, Y., and Takahashi, R. (2001). An unfolded putative transmembrane polypeptide, which can lead to endoplasmic reticulum stress, is a substrate of Parkin. Cell 105, 891-902. doi: 10.1016/s00928674(01)00407-x

Imbeaud, S., Faure, E., Lamarre, I., Mattéi, M. G., di Clemente, N., Tizard, R., et al. (1995). Insensitivity to anti-müllerian hormone due to a mutation in the human anti-müllerian hormone receptor. Nat. Genet. 11, 382-388. doi: $10.1038 /$ ng1295-382

Ishikawa, A., and Tsuji, S. (1996). Clinical analysis of 17 patients in 12 Japanese families with autosomal-recessive type juvenile parkinsonism. Neurology 47, 160-166. doi: 10.1212/wnl.47.1.160

John, A., Kizhakkedath, P., Al-Gazali, L., and Ali, B. R. (2015). Defective cellular trafficking of the bone morphogenetic protein receptor type II by mutations underlying familial pulmonary arterial hypertension. Gene 561, 148-156. doi: 10.1016/j.gene.2015.02.038

Johnson, D. W., Berg, J. N., Baldwin, M. A., Gallione, C. J., Marondel, I., Yoon, S. J., et al. (1996). Mutations in the activin receptor-like kinase 1 gene in hereditary haemorrhagic telangiectasia type 2. Nat. Genet. 13, 189-195. doi: 10.1038/ng0696- 189

Joshi, V., Upadhyay, A., Kumar, A., and Mishra, A. (2017). Gp78 E3 ubiquitin ligase: essential functions and contributions in proteostasis. Front. Cell Neurosci. 11:259. doi: 10.3389/fncel.2017.00259

Kaneko, M. (2016). Physiological roles of ubiquitin ligases related to the endoplasmic reticulum. Yakugaku Zasshi 136, 805-809. doi: 10.1248/yakushi. 15-00292-2

Kaneko, M., Imaizumi, K., Saito, A., Kanemoto, S., Asada, R., Matsuhisa, K., et al. (2017). ER stress and disease: toward prevention and treatment. Biol. Pharm. Bull. 40, 1337-1343. doi: 10.1248/bpb.b17-00342

Kaneko, M., Ishiguro, M., Niinuma, Y., Uesugi, M., and Nomura, Y. (2002). Human HRD1 protects against ER stress-induced apoptosis through ERassociated degradation. FEBS Lett. 532, 147-152. doi: 10.1016/s0014-5793(02) 03660-8

Karabegovic, A., Shinawi, M., Cymerman, U., and Letarte, M. (2004). No live individual homozygous for a novel endoglin mutation was found in a consanguineous Arab family with hereditary haemorrhagic telangiectasia. J. Med. Genet. 41, e119. doi: 10.1136/jmg.2004.022079

Karkera, J. D., Lee, J. S., Roessler, E., Banerjee-Basu, S., Ouspenskaia, M. V., Mez, J., et al. (2007). Loss-of-function mutations in growth differentiation factor-1 (GDF1) are associated with congenital heart defects in humans. Am. J. Hum. Genet. 81, 987-994. doi: 10.1086/522890

Kashima, R., and Hata, A. (2018). The role of TGF- $\beta$ superfamily signaling in neurological disorders. Acta Biochim. Biophys. Sin. 50, 106-120. doi: 10.1093/ abbs/gmx124

Kinoshita, A., Saito, T., Tomita, H., Makita, Y., Yoshida, K., Ghadami, M., et al. (2000). Domain-specific mutations in TGFB1 result in Camurati-Engelmann disease. Nat. Genet. 26, 19-20. doi: 10.1038/79128

Kizhakkedath, P., John, A., Al-Gazali, L., and Ali, B. R. (2018). Degradation routes of trafficking-defective VLDLR mutants associated with Dysequilibrium syndrome. Sci. Rep. 8:1583. doi: 10.1038/s41598-017-19053-8

Kizhakkedath, P., John, A., Al-Sawafi, B. K., Al-Gazali, L., and Ali, B. R. (2019). Endoplasmic reticulum quality control of LDLR variants associated with familial hypercholesterolemia. FEBS Open Bio. 9, 1994-2005. doi: 10.1002/ 2211-5463.12740

Kosaki, R., Gebbia, M., Kosaki, K., Lewin, M., Bowers, P., Towbin, J. A., et al. (1999). Left-right axis malformations associated with mutations in ACVR2B, the gene for human activin receptor type IIB. Am. J. Med. Genet. 82, 70-76.

Kotlarz, D., Marquardt, B., Barøy, T., Lee, W. S., Konnikova, L., Hollizeck, S., et al. (2018). Human TGF- $\beta 1$ deficiency causes severe inflammatory bowel disease and encephalopathy. Nat. Genet. 50, 344-348. doi: 10.1038/s41588-018-0063-6

Lamouille, S., Connolly, E., Smyth, J. W., Akhurst, R. J., and Derynck, R. (2012). TGF- $\beta$-induced activation of mTOR complex 2 drives epithelial-mesenchymal transition and cell invasion. J. Cell Sci. 125(Pt. 5), 1259-1273. doi: 10.1242/jcs. 095299 
Lander, E. S., Linton, L. M., Birren, B., Nusbaum, C., Zody, M. C., Baldwin, J., et al. (2001). Initial sequencing and analysis of the human genome. Nature 409, 860-921. doi: 10.1038/35057062

Lane, K. B., Machado, R. D., Pauciulo, M. W., Thomson, J. R., Phillips, J. A., Loyd, J. E., et al. (2000). Heterozygous germline mutations in BMPR2, encoding a TGF-beta receptor, cause familial primary pulmonary hypertension. Nat. Genet. 26, 81-84. doi: 10.1038/79226

Le Goff, C., Mahaut, C., Abhyankar, A., Le Goff, W., Serre, V., Afenjar, A., et al. (2011). Mutations at a single codon in Mad homology 2 domain of SMAD4 cause Myhre syndrome. Nat. Genet. 44, 85-88. doi: 10.1038/ng.1016

Lehmann, K., Seemann, P., Stricker, S., Sammar, M., Meyer, B., Süring, K., et al. (2003). Mutations in bone morphogenetic protein receptor $1 \mathrm{~B}$ cause brachydactyly type A2. Proc. Natl. Acad. Sci. U.S.A. 100, 12277-12282. doi: 10.1073/pnas. 2133476100

Lemus, L., and Goder, V. (2014). Regulation of Endoplasmic Reticulum-Associated Protein Degradation (ERAD) by Ubiquitin. Cells 3, 824-847. doi: 10.3390/ cells 3030824

Li, W., Dunmore, B. J., and Morrell, N. W. (2010). Bone morphogenetic protein type II receptor mutations causing protein misfolding in heritable pulmonary arterial hypertension. Proc. Am. Thorac. Soc. 7, 395-398. doi: 10.1513/pats. 201002-024AW

Lindsay, M. E., Schepers, D., Bolar, N. A., Doyle, J. J., Gallo, E., Fert-Bober, J., et al. (2012). Loss-of-function mutations in TGFB2 cause a syndromic presentation of thoracic aortic aneurysm. Nat. Genet. 44, 922-927. doi: 10.1038/ng.2349

Loeys, B. L., Chen, J., Neptune, E. R., Judge, D. P., Podowski, M., Holm, T., et al. (2005). A syndrome of altered cardiovascular, craniofacial, neurocognitive and skeletal development caused by mutations in TGFBR1 or TGFBR2. Nat. Genet. 37, 275-281. doi: 10.1038/ng1511

Luo, K. (2017). Signaling Cross Talk between TGF- $\beta /$ Smad and Other Signaling Pathways. Cold Spring Harb. Perspect. Biol. 9:a022137. doi: 10.1101/cshperspect. a022137

Machado, R. D., Eickelberg, O., Elliott, C. G., Geraci, M. W., Hanaoka, M., Loyd, J. E., et al. (2009). Genetics and genomics of pulmonary arterial hypertension. J. Am. Coll. Cardiol. 54 (Suppl. 1), S32-S42. doi: 10.1016/j.jacc.2009.04.015

Machado, R. D., Pauciulo, M. W., Thomson, J. R., Lane, K. B., Morgan, N. V., Wheeler, L., et al. (2001). BMPR2 haploinsufficiency as the inherited molecular mechanism for primary pulmonary hypertension. Am. J. Hum. Genet. 68, 92-102. doi: 10.1086/316947

Mallet, C., Lamribet, K., Giraud, S., Dupuis-Girod, S., Feige, J. J., Bailly, S., et al. (2015). Functional analysis of endoglin mutations from hereditary hemorrhagic telangiectasia type 1 patients reveals different mechanisms for endoglin loss of function. Hum. Mol. Genet. 24, 1142-1154. doi: 10.1093/hmg/ddu531

Markowitz, S., Wang, J., Myeroff, L., Parsons, R., Sun, L., Lutterbaugh, J., et al. (1995). Inactivation of the type II TGF-beta receptor in colon cancer cells with microsatellite instability. Science 268, 1336-1338. doi: 10.1126/science.7761852

Martínez-Glez, V., Valencia, M., Caparrós-Martín, J. A., Aglan, M., Temtamy, S., Tenorio, J., et al. (2012). Identification of a mutation causing deficient BMP1/mTLD proteolytic activity in autosomal recessive osteogenesis imperfecta. Hum. Mutat. 33, 343-350. doi: 10.1002/humu.21647

Massagué, J. (2008). A very private TGF-beta receptor embrace. Mol. Cell 29, 149-150. doi: 10.1016/j.molcel.2008.01.006

Massagué, J., Blain, S. W., and Lo, R. S. (2000). TGFbeta signaling in growth control, cancer, and heritable disorders. Cell 103, 295-309. doi: 10.1016/s00928674(00)00121-5

Massagué, J., and Chen, Y. G. (2000). Controlling TGF-beta signaling. Genes Dev. $14,627-644$

McAllister, K. A., Grogg, K. M., Johnson, D. W., Gallione, C. J., Baldwin, M. A., Jackson, C. E., et al. (1994). Endoglin, a TGF-beta binding protein of endothelial cells, is the gene for hereditary haemorrhagic telangiectasia type 1. Nat. Genet. 8, 345-351. doi: 10.1038/ng1294-345

McDonald, J., Damjanovich, K., Millson, A., Wooderchak, W., Chibuk, J. M., Stevenson, D. A., et al. (2011). Molecular diagnosis in hereditary hemorrhagic telangiectasia: findings in a series tested simultaneously by sequencing and deletion/duplication analysis. Clin. Genet. 79, 335-344. doi: 10.1111/j.13990004.2010.01596.x

Mehnert, M., Sommer, T., and Jarosch, E. (2010). ERAD ubiquitin ligases: multifunctional tools for protein quality control and waste disposal in the endoplasmic reticulum. Bioessays 32, 905-913. doi: 10.1002/bies.201000046
Mercado, G., Castillo, V., Soto, P., and Sidhu, A. (2016). ER stress and Parkinson's disease: Pathological inputs that converge into the secretory pathway. Brain Res. 1648(Pt. B), 626-632.

Milhem, R. M., and Ali, B. R. (2019). Disorders of FZ-CRD; insights towards FZCRD folding and therapeutic landscape. Mol. Med. 26:4. doi: 10.1186/s10020019-0129-7

Miyamoto, Y., Mabuchi, A., Shi, D., Kubo, T., Takatori, Y., Saito, S., et al. (2007). A functional polymorphism in the $5^{\prime}$ UTR of GDF5 is associated with susceptibility to osteoarthritis. Nat Genet. 39, 529-533. doi: 10.1038/2005

Mohamed, F. E., Al Sorkhy, M., Ghattas, M. A., Al-Gazali, L., Al-Dirbashi, O., Al-Jasmi, F., et al. (2020). The pharmacological chaperone N-n-butyldeoxygalactonojirimycin enhances $\beta$-galactosidase processing and activity in fibroblasts of a patient with infantile GM1-gangliosidosis. Hum. Genet. 139, 657-673. doi: 10.1007/s00439-020-02153-3

Morrell, N. W., Aldred, M. A., Chung, W. K., Elliott, C. G., Nichols, W. C., Soubrier, F., et al. (2019). Genetics and genomics of pulmonary arterial hypertension. Eur. Respir. J. 53, 1801899. doi: 10.1183/13993003.01899-2018

Moustakas, A., and Heldin, C. H. (2005). Non-Smad TGF-beta signals. J. Cell Sci. 118(Pt 16), 3573-3584. doi: 10.1242/jcs.02554

Moustakas, A., and Heldin, C. H. (2009). The regulation of TGFbeta signal transduction. Development 136, 3699-3714. doi: 10.1242/dev.030338

Needham, P. G., and Brodsky, J. L. (2013). How early studies on secreted and membrane protein quality control gave rise to the ER associated degradation (ERAD) pathway: the early history of ERAD. Biochim. Biophys. Acta 1833, 2447-2457. doi: 10.1016/j.bbamcr.2013.03.018

Nishikawa, S., Brodsky, J. L., and Nakatsukasa, K. (2005). Roles of molecular chaperones in endoplasmic reticulum (ER) quality control and ERassociated degradation (ERAD). J. Biochem. 137, 551-555. doi: 10.1093/jb/ mvi068

Nishitoh, H., Kadowaki, H., Nagai, A., Maruyama, T., Yokota, T., Fukutomi, H., et al. (2008). ALS-linked mutant SOD1 induces ER stress- and ASK1-dependent motor neuron death by targeting Derlin-1. Genes Dev. 22, 1451-1464. doi: 10.1101/gad.1640108

Nishitoh, H., Matsuzawa, A., Tobiume, K., Saegusa, K., Takeda, K., Inoue, K., et al. (2002). ASK1 is essential for endoplasmic reticulum stress-induced neuronal cell death triggered by expanded polyglutamine repeats. Genes Dev. 16, 1345-1355. doi: 10.1101/gad.992302

Nolan-Stevaux, O., Zhong, W., Culp, S., Shaffer, K., Hoover, J., Wickramasinghe, D., et al. (2012). Endoglin requirement for BMP9 signaling in endothelial cells reveals new mechanism of action for selective anti-endoglin antibodies. PLoS One 7:e50920. doi: 10.1371/journal.pone.0050920

Oda, Y., Hosokawa, N., Wada, I., and Nagata, K. (2003). EDEM as an acceptor of terminally misfolded glycoproteins released from calnexin. Science 299, 1394-1397. doi: 10.1126/science. 1079181

Ollauri-Ibáñez, C., López-Novoa, J. M., and Pericacho, M. (2017). Endoglin-based biological therapy in the treatment of angiogenesis-dependent pathologies. Exp. Opin. Biol. Ther. 17, 1053-1063. doi: 10.1080/14712598.2017.1346607

Olzmann, J. A., Kopito, R. R., and Christianson, J. C. (2013). The mammalian endoplasmic reticulum-associated degradation system. Cold Spring Harb. Perspect. Biol. 5:a013185. doi: 10.1101/cshperspect.a013185

Ozdamar, B., Bose, R., Barrios-Rodiles, M., Wang, H. R., Zhang, Y., and Wrana, J. L. (2005). Regulation of the polarity protein Par6 by TGFbeta receptors controls epithelial cell plasticity. Science 307, 1603-1609. doi: 10.1126/science. 1105718

Pavlidis, E. T., and Pavlidis, T. E. (2013). Role of bevacizumab in colorectal cancer growth and its adverse effects: a review. World J. Gastroenterol. 19, 5051-5060. doi: 10.3748/wjg.v19.i31.5051

Pérez-Gómez, E., Del Castillo, G., Juan Francisco, S., López-Novoa, J. M., Bernabéu, C., and Quintanilla, M. (2010). The role of the TGF- $\beta$ coreceptor endoglin in cancer. Sci. World J. 10, 2367-2384. doi: 10.1100/tsw.2010.230

Pickart, C. M., and Cohen, R. E. (2004). Proteasomes and their kin: proteases in the machine age. Nat. Rev. Mol. Cell Biol. 5, 177-187. doi: 10.1038/nrm1336

Plöger, F., Seemann, P., Schmidt-von Kegler, M., Lehmann, K., Seidel, J., Kjaer, K. W., et al. (2008). Brachydactyly type A2 associated with a defect in proGDF5 processing. Hum. Mol. Genet. 17, 1222-1233. doi: 10.1093/hmg/ddn012

Polinkovsky, A., Robin, N. H., Thomas, J. T., Irons, M., Lynn, A., Goodman, F. R., et al. (1997). Mutations in CDMP1 cause autosomal dominant brachydactyly type C. Nat. Genet. 17, 18-19. doi: 10.1038/ng0997-18 
Preston, G. M., and Brodsky, J. L. (2017). The evolving role of ubiquitin modification in endoplasmic reticulum-associated degradation. Biochem. J. 474, 445-469. doi: 10.1042/BCJ20160582

Qi, L., Tsai, B., and Arvan, P. (2017). New insights into the physiological role of endoplasmic reticulum-associated degradation. Trends Cell Biol. 27, 430-440. doi: $10.1016 /$ j.tcb.2016.12.002

Racacho, L., Byrnes, A. M., MacDonald, H., Dranse, H. J., Nikkel, S. M., Allanson, J., et al. (2015). Two novel disease-causing variants in BMPR1B are associated with brachydactyly type A1. Eur. J. Hum. Genet. 23, 1640-1645. doi: 10.1038/ ejhg. 2015.38

Rampazzo, A., Beffagna, G., Nava, A., Occhi, G., Bauce, B., Noiato, M., et al. (2003). Arrhythmogenic right ventricular cardiomyopathy type 1 (ARVD1): confirmation of locus assignment and mutation screening of four candidate genes. Eur. J. Hum. Genet. 11, 69-76. doi: 10.1038/sj.ejhg.5200914

Ricard, N., Bidart, M., Mallet, C., Lesca, G., Giraud, S., Prudent, R., et al. (2010). Functional analysis of the BMP9 response of ALK1 mutants from HHT2 patients: a diagnostic tool for novel ACVRL1 mutations. Blood 116, 1604-1612. doi: 10.1182/blood-2010-03-276881

Richards-Yutz, J., Grant, K., Chao, E. C., Walther, S. E., and Ganguly, A. (2010). Update on molecular diagnosis of hereditary hemorrhagic telangiectasia. Hum. Genet. 128, 61-77. doi: 10.1007/s00439-010-0825-4

Rienhoff, H. Y., Yeo, C. Y., Morissette, R., Khrebtukova, I., Melnick, J., Luo, S., et al. (2013). A mutation in TGFB3 associated with a syndrome of low muscle mass, growth retardation, distal arthrogryposis and clinical features overlapping with Marfan and Loeys-Dietz syndrome. Am. J. Med. Genet. A 161A, 2040-2046. doi: 10.1002/ajmg.a.36056

Robert, F., Desroches-Castan, A., Bailly, S., Dupuis-Girod, S., and Feige, J. J. (2020). Future treatments for hereditary hemorrhagic telangiectasia. Orphanet. J. Rare Dis. 15:4. doi: 10.1186/s13023-019-1281-4

Ruggiano, A., Foresti, O., and Carvalho, P. (2014). Quality control: ER-associated degradation: protein quality control and beyond. J. Cell Biol. 204, 869-879. doi: $10.1083 /$ jcb. 201312042

Ruiz, S., Chandakkar, P., Zhao, H., Papoin, J., Chatterjee, P. K., Christen, E., et al. (2017). Tacrolimus rescues the signaling and gene expression signature of endothelial ALK1 loss-of-function and improves HHT vascular pathology. Hum. Mol. Genet. 26, 4786-4798. doi: 10.1093/hmg/ddx358

Sadick, H., Naim, R., Gössler, U., Hörmann, K., and Riedel, F. (2005). Angiogenesis in hereditary hemorrhagic telangiectasia: VEGF165 plasma concentration in correlation to the VEGF expression and microvessel density. Int. J. Mol. Med. $15,15-19$.

Satow, R., Kurisaki, A., Chan, T. C., Hamazaki, T. S., and Asashima, M. (2006). Dullard promotes degradation and dephosphorylation of BMP receptors and is required for neural induction. Dev. Cell 11, 763-774. doi: 10.1016/j.devcel.2006. 10.001

Seemann, P., Schwappacher, R., Kjaer, K. W., Krakow, D., Lehmann, K., Dawson, K., et al. (2005). Activating and deactivating mutations in the receptor interaction site of GDF5 cause symphalangism or brachydactyly type A2. J. Clin. Invest. 115, 2373-2381. doi: 10.1172/JCI25118

Sha, H., He, Y., Yang, L., and Qi, L. (2011). Stressed out about obesity: IRE1 $\alpha-X B P 1$ in metabolic disorders. Trends Endocrinol. Metab. 22, 374-381. doi: 10.1016/j. tem.2011.05.002

Shao, E. S., Lin, L., Yao, Y., and Boström, K. I. (2009). Expression of vascular endothelial growth factor is coordinately regulated by the activin-like kinase receptors 1 and 5 in endothelial cells. Blood 114, 197-206. doi: 10.1182/blood2009-01- 199166

Shi, Y., and Massagué, J. (2003). Mechanisms of TGF-beta signaling from cell membrane to the nucleus. Cell 113, 685-700.

Shintani, M., Yagi, H., Nakayama, T., Saji, T., and Matsuoka, R. (2009). A new nonsense mutation of SMAD8 associated with pulmonary arterial hypertension. J. Med. Genet. 46, 331-337. doi: 10.1136/jmg.2008.062703

Shore, E. M., Xu, M., Feldman, G. J., Fenstermacher, D. A., Cho, T. J., Choi, I. H., et al. (2006). A recurrent mutation in the BMP type I receptor ACVR1 causes inherited and sporadic fibrodysplasia ossificans progressiva. Nat. Genet. 38, 525-527. doi: 10.1038/ng1783

Simonneau, G., Gatzoulis, M. A., Adatia, I., Celermajer, D., Denton, C., Ghofrani, A., et al. (2013). Updated clinical classification of pulmonary hypertension. J. Am. Coll. Cardiol. 62, D34-D41. doi: 10.1016/j.jacc.2013.10.029
Sobolewski, A., Rudarakanchana, N., Upton, P. D., Yang, J., Crilley, T. K., Trembath, R. C., et al. (2008). Failure of bone morphogenetic protein receptor trafficking in pulmonary arterial hypertension: potential for rescue. Hum. Mol. Genet. 17, 3180-3190. doi: 10.1093/hmg/ddn214

Sommer, N., Droege, F., Gamen, K. E., Geisthoff, U., Gall, H., Tello, K., et al. (2019). Treatment with low-dose tacrolimus inhibits bleeding complications in a patient with hereditary hemorrhagic telangiectasia and pulmonary arterial hypertension. Pulm. Circ. 9:2045894018805406. doi: 10. $1177 / 2045894018805406$

Spiekerkoetter, E., Sung, Y. K., Sudheendra, D., Bill, M., Aldred, M. A., van de Veerdonk, M. C., et al. (2015). Low-Dose FK506 (Tacrolimus) in end-stage pulmonary arterial hypertension. Am. J. Respir. Crit. Care Med. 192, 254-257. doi: 10.1164/rccm.201411-2061LE

Stevenson, J., Huang, E. Y., and Olzmann, J. A. (2016). Endoplasmic ReticulumAssociated Degradation and Lipid Homeostasis. Annu. Rev. Nutr. 36, 511-542.

Stolz, A., Hilt, W., Buchberger, A., and Wolf, D. H. (2011). Cdc48: a power machine in protein degradation. Trends Biochem. Sci. 36, 515-523. doi: 10.1016/j.tibs. 2011.06.001

Sun, Z., and Brodsky, J. L. (2019). Protein quality control in the secretory pathway. J. Cell Biol. 218, 3171-3187. doi: 10.1083/jcb.201906047

Suzuki, S., Marazita, M. L., Cooper, M. E., Miwa, N., Hing, A., Jugessur, A., et al. (2009). Mutations in BMP4 are associated with subepithelial, microform, and overt cleft lip. Am. J. Hum. Genet. 84, 406-411. doi: 10.1016/j.ajhg.2009. 02.002

Tan, H. L., Glen, E., Töpf, A., Hall, D., O’Sullivan, J. J., Sneddon, L., et al. (2012). Nonsynonymous variants in the SMAD6 gene predispose to congenital cardiovascular malformation. Hum. Mutat. 33, 720-727. doi: 10.1002/humu. 22030

Tan, T. Y., Gonzaga-Jauregui, C., Bhoj, E. J., Strauss, K. A., Brigatti, K., Puffenberger, E., et al. (2017). Monoallelic BMP2 variants predicted to result in haploinsufficiency cause craniofacial, skeletal, and cardiac features overlapping those of 20p12 deletions. Am. J. Hum. Genet. 101, 985-994. doi: 10.1016/j.ajhg. 2017.10.006

Tax, G., Lia, A., Santino, A., and Roversi, P. (2019). Modulation of ERQC and ERAD: a broad-spectrum spanner in the works of cancer cells? J. Oncol. 2019:8384913. doi: 10.1155/2019/8384913

Teo, S. K. (2005). Properties of thalidomide and its analogues: implications for anticancer therapy. AAPS J. 7, E14-E19. doi: 10.1208/aapsj070103

Thenappan, T., Ormiston, M. L., Ryan, J. J., and Archer, S. L. (2018). Pulmonary arterial hypertension: pathogenesis and clinical management. BMJ 360:j5492. doi: 10.1136/bmj.j5492

Thomas, J. T., Kilpatrick, M. W., Lin, K., Erlacher, L., Lembessis, P., Costa, T., et al. (1997). Disruption of human limb morphogenesis by a dominant negative mutation in CDMP1. Nat. Genet. 17, 58-64. doi: 10.1038/ng0997-58

Timberlake, A. T., Choi, J., Zaidi, S., Lu, Q., Nelson-Williams, C., Brooks, E. D., et al. (2016). Two locus inheritance of non-syndromic midline craniosynostosis via rare. eLife 5:e20125. doi: 10.7554/eLife.20125

Tzavlaki, K., and Moustakas, A. (2020). TGF- $\beta$ Signaling. Biomolecules 10:487. doi: 10.3390/biom10030487

van de Laar, I. M., Oldenburg, R. A., Pals, G., Roos-Hesselink, J. W., de Graaf, B. M., Verhagen, J. M., et al. (2011). Mutations in SMAD3 cause a syndromic form of aortic aneurysms and dissections with early-onset osteoarthritis. Nat. Genet. 43, 121-126. doi: 10.1038/ng.744

Vander Ark, A., Cao, J., and Li, X. (2018). TGF- $\beta$ receptors: in and beyond TGF- $\beta$ signaling. Cell Signal. 52, 112-120. doi: 10.1016/j.cellsig.2018.09.002

Vashist, S., and Ng, D. T. (2004). Misfolded proteins are sorted by a sequential checkpoint mechanism of ER quality control. J. Cell Biol. 165, 41-52. doi: $10.1083 /$ jcb. 200309132

Vij, N., Fang, S., and Zeitlin, P. L. (2006). Selective inhibition of endoplasmic reticulum-associated degradation rescues DeltaF508-cystic fibrosis transmembrane regulator and suppresses interleukin-8 levels: therapeutic implications. J. Biol. Chem. 281, 17369-17378. doi: 10.1074/jbc.M600509200

Vorselaars, V. M. M., Hosman, A. E., Westermann, C. J. J., Snijder, R. J., Mager, J. J., Goumans, M. J., et al. (2018). Pulmonary arterial hypertension and hereditary haemorrhagic telangiectasia. Int. J. Mol. Sci. 19, 230-237. doi: 10. 3390/ijms19103203 
Wang, F., Song, W., Brancati, G., and Segatori, L. (2011). Inhibition of endoplasmic reticulum-associated degradation rescues native folding in loss of function protein misfolding diseases. J. Biol. Chem. 286, 43454-43464. doi: 10.1074/jbc. M111.274332

Wang, G., Fan, R., Ji, R., Zou, W., Penny, D. J., Varghese, N. P., et al. (2016). Novel homozygous BMP9 nonsense mutation causes pulmonary arterial hypertension: a case report. BMC Pulm. Med. 16:17. doi: 10.1186/s12890-0160183-7

Wu, X., and Rapoport, T. A. (2018). Mechanistic insights into ER-associated protein degradation. Curr. Opin. Cell Biol. 53, 22-28. doi: 10.1016/j.ceb.2018. 04.004

Yang, Y., Zheng, Y., Li, W., Li, L., Tu, M., Zhao, L., et al. (2019). Correction: SMAD6 is frequently mutated in nonsyndromic radioulnar synostosis. Genet. Med. 21:2409. doi: 10.1038/s41436-019-0578-y

Ye, M., Berry-Wynne, K. M., Asai-Coakwell, M., Sundaresan, P., Footz, T., French, C. R., et al. (2010). Mutation of the bone morphogenetic protein GDF3 causes ocular and skeletal anomalies. Hum. Mol. Genet. 19, 287-298. doi: 10.1093/ hmg/ddp496

Yi, J. Y., Shin, I., and Arteaga, C. L. (2005). Type I transforming growth factor beta receptor binds to and activates phosphatidylinositol 3-kinase. J. Biol. Chem. 280, 10870-10876. doi: 10.1074/jbc.M413223200
Yu, L., Hébert, M. C., and Zhang, Y. E. (2002). TGF-beta receptor-activated p38 MAP kinase mediates Smad-independent TGF-beta responses. EMBO J. 21, 3749-3759. doi: 10.1093/emboj/cdf366

Zhang, Y. E. (2009). Non-Smad pathways in TGF-beta signaling. Cell Res. 19, 128-139. doi: 10.1038/cr.2008.328

Zhu, W., Chen, W., Zou, D., Wang, L., Bao, C., Zhan, L., et al. (2018). Thalidomide reduces hemorrhage of brain arteriovenous malformations in a mouse model. Stroke 49, 1232-1240. doi: 10.1161/STROKEAHA.117.020356

Zito, E. (2019). Targeting ER stress/ER stress response in myopathies. Redox Biol. 26:101232. doi: 10.1016/j.redox.2019.101232

Conflict of Interest: The authors declare that the research was conducted in the absence of any commercial or financial relationships that could be construed as a potential conflict of interest.

Copyright (c) 2020 Gariballa and Ali. This is an open-access article distributed under the terms of the Creative Commons Attribution License (CC BY). The use, distribution or reproduction in other forums is permitted, provided the original author(s) and the copyright owner(s) are credited and that the original publication in this journal is cited, in accordance with accepted academic practice. No use, distribution or reproduction is permitted which does not comply with these terms. 